$1-1981$

\title{
Archeological Investigations at the Laredo Cemetery Site (41WB22), Webb County, Texas
}

Mary Jane McReynolds

Prewitt and Associates, Inc.

LaVerne Herrington

Prewitt and Associates, Inc.

Ken Rodgers

Prewitt and Associates, Inc.

Follow this and additional works at: https://scholarworks.sfasu.edu/ita

Part of the American Material Culture Commons, Archaeological Anthropology Commons, Environmental Studies Commons, Other American Studies Commons, Other Arts and Humanities Commons, Other History of Art, Architecture, and Archaeology Commons, and the United States History Commons

Tell us how this article helped you.

This Article is brought to you for free and open access by the Center for Regional Heritage Research at SFA ScholarWorks. It has been accepted for inclusion in Index of Texas Archaeology: Open Access Gray Literature from the Lone Star State by an authorized editor of SFA ScholarWorks. For more information, please contact cdsscholarworks@sfasu.edu. 


\section{Archeological Investigations at the Laredo Cemetery Site (41WB22), Webb County, Texas}

\section{Creative Commons License}

\section{(c) (1) (8)}

This work is licensed under a Creative Commons Attribution-NonCommercial 4.0 International License 


\title{
ARCHEOLOGICAL INVESTIGATIONS AT THE \\ LAREDO CEMETERY SITE (4IWB22), \\ WEBB COUNTY, TEXAS
}

\author{
by \\ Mary Jane McReynolds \\ with Contributions by \\ LaVerne Herrington \\ and Ken Rogers
}

PRINCIPAL INVESTIGATOR: Elton R. Prewitt

REPORTS OF INVESTIGATIONS, NUMBER 11

Prewitt and Associates, Inc.

Consulting Archeologists

Austin, Texas

January 1981 
Report submitted to the City of Laredo, Engineering Department, Laredo, Texas, under the terms of State of Texas Antiquities Permit No. 240 issued by the Texas Antiquities Committee. 
TABLE OF CONTENTS

Foreword . . . . . . . . . . . . . v

Abstract . . . . . . . . . . . . . . . vi

Acknowledgments . . . . . . . . . . . . vii

Introduction ................ . . 1

Environmental Setting ............. 2

Historical Background .............. 4

Archeological Background ............. 7

Archeological Procedures . . . . . . . . . . 12

Description of the Graves . . . . . . . . . . 15

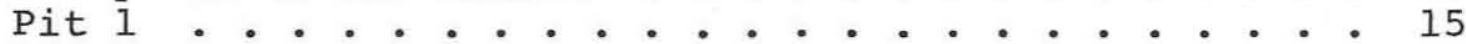

Pit 2 . . . . . . . . . . . . . 22

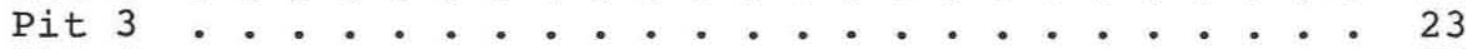

Pit 4 .................. . 27

Pit 5................ 34

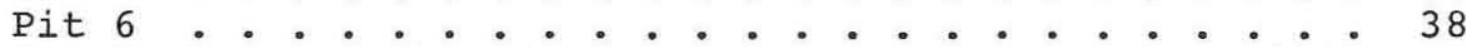

Pit 7 ................ 40

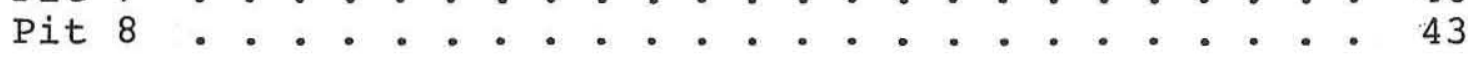

Discussion ............ 57

Glossary .............. . . 65

References Cited ............. . 66

Additional References Regarding Funerary Practices . . 69

Appendix I: Additional Monitoring Mary Jane McReynolds . . . . . . . . . . 71

Appendix II: A Preliminary Analysis of Skeletal Remains from the Laredo Cemetery

Site - LaVerne Herrington and Mary Jane McReynolds . . 77

Appendix III: Identification of Wood Used

in Coffin Construction, The Laredo Cemetery

Site - Ken Rogers and Mary Jane MeReynolds..... 83

Appendix IV: A Brief History of Coffins -

Mary Jane McReynolds .............. 91 
1. Project location map .......... . 3

2. 1890's perspective map of the City of Laredo . . . . . . . . . . . 9

3. Enlargement of a portion of 1890's map of Laredo . . . . . . . . . . . 11

4. Site map ............ . . 13

5. Truncated diamond style coffin ...... 15

6. Pit 1............. . . 17

7. Coffin hardware from Grave 1-7...... . 21

8. Pit 3............. . . 25

9. Pit 4............... 29

10. Coffin hardware from Graves $4-1$ and 5-1 . . 31

11. Pit 5 . . . . . . . . . 35

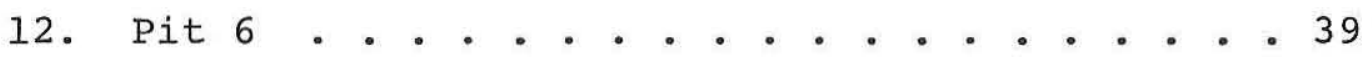

13. Pit 7 ................... 41

14. Pit 8 . . . . . . . . . . 44

15. Coffin hardware from Grave 8-1 . . . . . 47

16. Coffin hardware from Grave 8-1 . . . . . . 49

17. Photograph of Grave 8-1 . . . . . . . 51

18. Coffin hardware from Grave 8-3...... 54

19. Pit 10 . . . . . . . . . 75

\section{LIST OF TABLES}

1. Distribution of removal of skeletal remains . . . . . . . . . . 57

2. Distribution of age and sex ...... . 58

3. Distribution of cultural materials . . . . 60

4. Artifact summary . . . . . . . . . 61

5. Excavated graves . . . . . . . . . 82

6. Wood types from coffins recovered from the Laredo Cemetery Site . . . . . 87 
FOREWORD

Archeological involvement in the exhumation of relatively recent historic cemeteries is a new development in Texas. Traditionally, archeologists have directed their attention toward the burial practices of aboriginal peoples and have shied away from any dealings with the excavations of late nineteenth and early twentieth century cemeteries. This trend has continued despite an ever-increasing awareness of and concern with changing modes of historic and recent tombstone embellishment on the part of archeologists, cultural anthropologists and historians. In practice, tombstones have been studied sporadically but the tasks of relocation and reinterment of the physical human remains have been left to undertakers and professional cemetery movers. The present report authored by Mary Jane McReynolds describes the results of limited archeological investigations at the Laredo Cemetery Site (41WB22) in the City of Laredo, Texas. The investigations resulted from an emergency situation in which a forgotten cemetery was rediscovered in the midst of a construction project. The need for rapid action precluded the development of a thorough problemoriented research design and consequently led to the adoption of a severely limited scope of investigations. Despite these problems, Ms. McReynolds has presented significant new data for archeologists in terms of coffin styles, coffin decorations, and artifacts associated with various interments. While the report is not intended to be exhaustive, it does recount some of the problems encountered in this type of investigation and provides general suggestions for directing future research in historic cemetery sites. 
In Apriz, May and June of 1980, Prewitt and Associates, Inc. conducted archeological monitoring and excavations in specified areas of 41WB22, a late nineteenth and early twentieth century cemetery in the city of Laredo, Webb county, Texas. These investigations were directly solely towards locating and removing graves exposed by pit and trench excavation activities at the construction site of the Laredo Transit operating Facilities. The result was the accumulation of data regarding the disinterment of twenty-two graves which contained twenty-three individuals; six of these were partially or totally removed during backhoe excavations prior to the initiation of archeological monitoring, and seventeen were systematically exposed, recorded and removed after the commencement of monitoring. An additional thirteen grave out lines were detected and their locations recorded but their contents were not exhumed. 


\section{ACKNOWLEDGMENTS}

An unusual excavation such as this one involves the cooperation and assistance of many people in all aspects of the project for its successful completion. Special thanks go to LaVerne Herrington, Texas Antiquities Committee; John Hickey of the architectural firm of Turner, Hickey and Associates; Alfredo Paiz, Superintendent in charge of construction for Century Structures, Inc.; and Century Structures personnel who patiently assisted during various phases of the monitoring and excavation. Thanks also go to Amador Escudero and all of the personnel of the City of Laredo Engineering Department for helpful assistance provided. Christine de Bremaeker and Mary Humphrey served admirably as crew persons during the field work. Special thanks are extended to Charles Locke and his assistant, Ulrich Kleinschmidt, of the Antiquities Conservation Laboratory, The University of Texas at Austin for cleaning and identifying the metals of the coffin hardware. Ken Rogers of the Texas Forest Products Laboratory, Texas Forest Service, identified the wood samples from the coffins, and LaVerne Herrington identified and analyzed the skeletal materials. Linda Battles-Herron prepared the artifact illustrations, and Sandra Hannum and Kerza A. Prewitt did the drafting. Editing and typing of the final draft was done by Linda Nance and Elton Prewitt.

To all of these people, as well as others not mentioned here who aided in the successful completion of this project, I wish to express my sincerest gratitude for their support, advice, and above all, patience. 


\section{INTRODUCTION}

Archeological investigations of site 4 lWB22* were conducted by Prewitt and Associates, Inc. from April to June 1980. This site is an historic cemetery which covers a two-block area, including the street, within the City of Laredo, Webb County, Texas. Excavations were carried out in limited specified areas of the eastern portion of the site. The western portion of the site is occupied by the Laredo Boys Club; the site is divided by San Francisco Avenue (Fig. 1).

Construction workers preparing a pit for the installation of a 10,000-gallon underground fuel storage tank on the site discovered human skeletal remains and coffin remnants on March 30,1980 . Excavation of the 8feet-wide by 32-feet-long by 12-feet-deep pit on the south side of the site was approximately 75 percent completed before the workers realized human burials were being encountered. Construction activities were halted at that time; examination of the pit and backdirt revealed that six graves had been disrupted. Five of the interments were partially exposed within the walls of the pit while the sixth grave was apparently completely removed (Paiz 1980). Eight additional graves were discovered on the north side of the site where shallow trenches were dug to a depth of 40 inches while preparing the forms for pouring a concrete slab foundation for the planned terminal building. Each of these eight graves was

\footnotetext{
*Trinomial site designation assigned by the Texas Archeological Research Laboratory, The University of Texas at Austin; 41 indicates Texas in the alphabetical ordering of the states (excluding Alaska and Hawaii), WB indicates Webb County, and 22 indicates this is the twenty-second archeological site recorded in that county.
} 
found when grave fill collapsed into the cavities which remained after the deterioration of coffins and their human contents.

Consultations between the City of Laredo and the Texas Antiquities Committee resulted in a recommendation that archeological monitoring and limited excavations were necessary at the site. The City subsequently engaged Prewitt and Associates, Inc. to provide the required archeological services. Monitoring and salvage activities were carried out by the author from April 28 to May 2, 1980. The following week limited excavations were conducted with the assistance of two additional crew members. Additional monitoring and excavation on June 5 completed the field investigations for this project (see Appendix I).

\section{Environmental setting}

Webb County is situated within the Rio Grande Plain on the southwestern margins of the West Gulf Coastal Plain physiographic province (Carr 1967: 3; Fenneman 1938: 100120). It is in an area characterized by undulating irregular plains in which moderate slopes, wide valleys and ranges of low hills are predominant (Sellards, Adkins and Plummer 1932: 681; Arbingast et al 1976: 9). The surface geology within the study area consists of various formations assignable to the Jackson group of Cenozoic era Tertiary system strata (Sellards, Adkins and Plummer 1932: 677-682).

Soils within the project area are included within the Rio Grande Plains general soils area and consist primarily of neutral gray sandy loams with clay loam and clayey subsoils (Arbingast et al 1976: 12); these are classifiable as Pellusterts, Torrerts and Paleorthids 


\section{THE LAREDO CEMETERY SITE}

\section{WEBB COUNTY, TEXAS}

4 WB 22

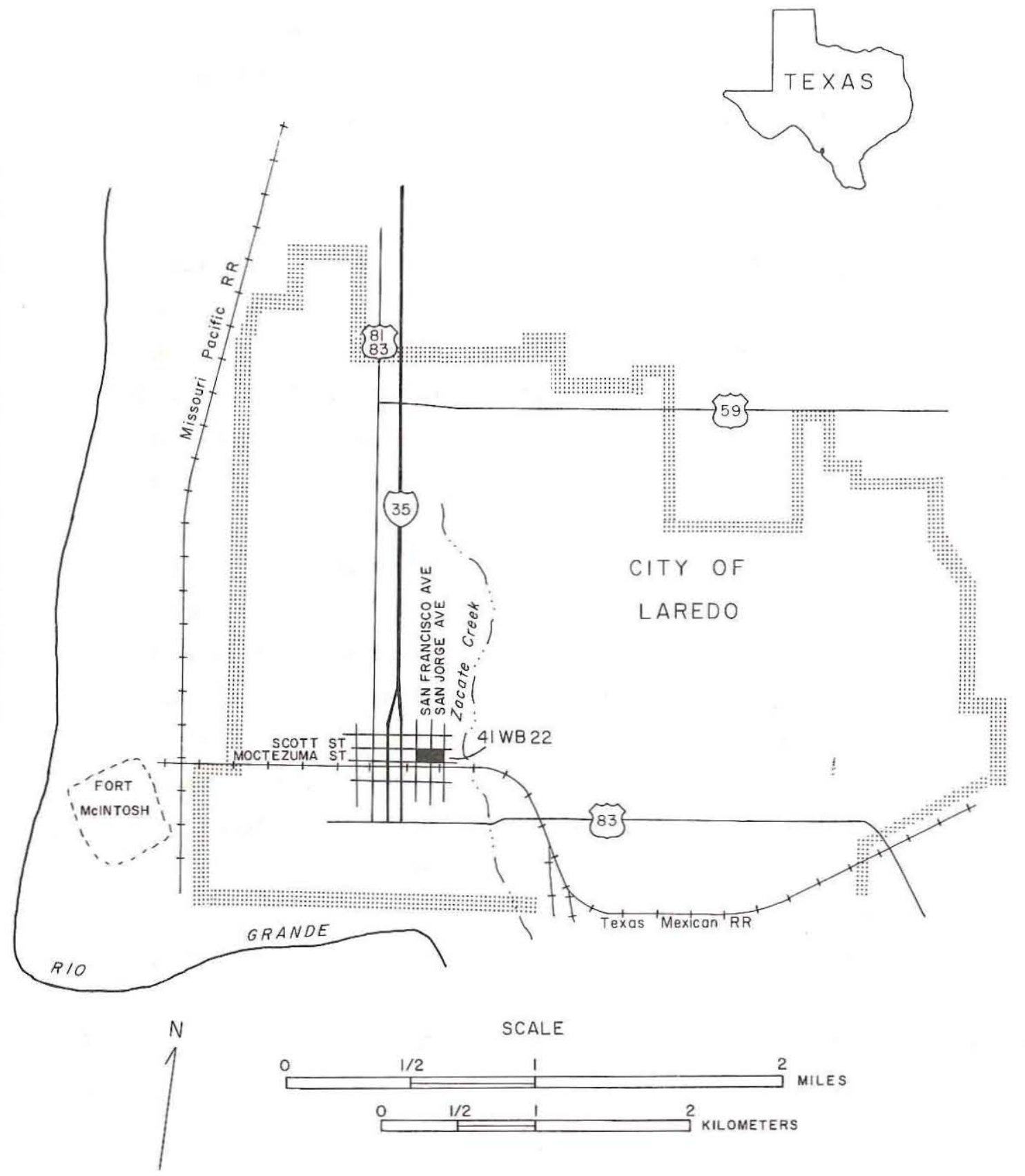


of the Catarina-Montell-Jimenez associations (Godfrey, McKee and Oakes 1973). Vegetation boundaries generally coincide with the soils groups; Blair includes the area within the Tamaulipan biotic province (1950: 102-105). The average annual precipitation is about 20 inches with the heaviest peaks occurring during the late Spring and early Fall; the mean annual temperature is 72。 (Carr 1967: 4, 6; Arbingast et al 1976: 17, 19).

\section{Historical Background}

The City of Laredo is a chief port of entry on the United States-Mexico border and is located in southwestern Webb County on the Rio Grande. Laredo, one of the older cities in Texas, was founded in May 1755 by Don Tomas Sanchez de la Barrera y Gallardo; colonization of the region was accomplished between 1723 and 1755 under the guidance of Jose de Escandon who had been commissioned by the viceroy of Mexico (Bolton 1970: 59). Twelve years after its founding (1767) the land was apportioned and the village of San Agustin de Laredo was formally surveyed and laid out. The nucleus of the city as described in the Acta de la General Visita del Pueblo de San Agustin de Laredo (Haynes 1767) is the same today as the original San Agustin Plaza area; the town radiated from this main square as it developed.

Citizens of Laredo had little to do with the Anglo-American settlement of Texas; they considered themselves to be citizens of Coahuila up to 1820 and of Tamaulipas by 1828. The first substantial intrusion of Anglo-Americans was brought about as a direct result of 
the Mexican War. It was not until 1846 that the Texas government was extended to the area. Mirabeau B. Lamar, under the direction of General Zachary Taylor, assumed command of the town during the Mexican War (Garcia 1970: 36).

The Texas Legislature created Webb County in January 1848 in honor of Judge James Webb who had served under Lamar while Lamar was President of the Texas Republic. The City of Laredo was incorporated in 1850.

In early 1881 economic interests were bolstered with the extension of the Texas-Mexican Railroad to Laredo from Corpus Christi and the arrival later that same year of the International and Great Northern Railroad from San Antonio. In 1889 the first electric street railway system west of the Mississippi River was constructed in Laredo (Falvella 1925).

Sometime in the late nineteenth and early twentieth centuries the block bordered by Scott Street, San Jorge Avenue, Moctezuma Street, and San Eduardo Avenue was used as a cemetery; however, it appears that virtually no records pertaining to this cemetery exist. It is reported that in the early part of this century the cemetery was cleared of many bodies there which were then moved to other cemeteries; furthermore, there reportedly was a Catholic section which was administered by St. Augustine Church, the only Catholic church in Laredo until 1895. The present church records, however, do not begin until 1917 and pertain to the present Catholic cemetery only (Monsignor Kevin Dunne 1980).

A records search has revealed little conclusive documentation of the cemetery. In the early 1920's the cemetery was apparently legally moved; however, responsibility 
for disinterment was left to friends or relatives of the individuals who had been buried there. It is likely that many friends and relatives had themselves passed away by this time or had moved from the Laredo area, while others possibly could not afford the expense of disinterment and reburial; it is probable that few of the graves were actually moved. The grave markers were evidently removed, however, and when this is combined with a lack of written records, the problems of learning who these individuals were and when they were interred are compounded. Examination of the contents of the graves is the only alternative which may be expected to provide basic information about the individuals buried there.

The only substantive documentation of this site as a cemetery comes from two sources; an 1890's perspective map of the City of Laredo and a 1918 map of Laredo attached to the 1920-21 Laredo City Directory (Foster 1918). The 1890's map shows the site as one oversized block or area instead of the two existing blocks (Figs. 2 and 3). When the 1918 map was prepared, San Francisco Avenue had been extended to the north separating 41 WB22 into two blocks as well as covering over a portion of the cemetery. The symbol of a cross appears in both of these blocks, but they are not identified as a cemetery or church. This same City Directory does not list an address for a cemetery or a church in either block (Foster 1918). In about 1923 ownership of the eastern portion/ block of the site was transferred to the City Transportation or street Department; the fact that this portion, as well as the western portion, had been a cemetery was subsequently forgotten. However, in 1940 when construction 
of the Laredo Boys Club was begun, coffins were reportedly unearthed.

Archeological Background

The sparse published reports of archeological research done in Webb County to date consist of descriptive reporting of cultural resources. Until recently, most archeological work in Webb County had been performed by students, amateurs and artifact collectors.

An archeological survey along portions of Zacate Creek within the City of Laredo was conducted in 1973; several prehistoric sites were recorded (Hall 1973). A later survey along the McPherson Road Extension Project resulted in minor testing at three archeological sites (Fox and Uecker 1977). Historic sites investigations have until recently been concentrated on the site of Fort McIntosh (Ivey, Medlin and Eaton 1977; Fox 1979). Additional investigations into both prehistoric and historic sites are being conducted by The University of Texas at San Antonio and the State Department of Highways and Public Transportation; it may be anticipated that the completion of reports detailing these investigations will contribute substantially to the extent of knowledge of the archeological record of Laredo.

Investigations into historic cemeteries in Texas have, in the past, usually dealt with isolated interments of aboriginal people (e.g., Newcomb 1958; Suhm 1962) or with aboriginal cemeteries associated with early Spanish missions (e.g., Schuetz 1968; Gilmore 1969). It is beyond the scope of this report to provide a detailed history of cemetery investigations, but a review of the literature 
Figure 2. 1890's perspective map of the City of Laredo showing cemetery location in upper center portion of map. Source: 1920-1921 Laredo City Directory (Foster 1918). 
Figure 2

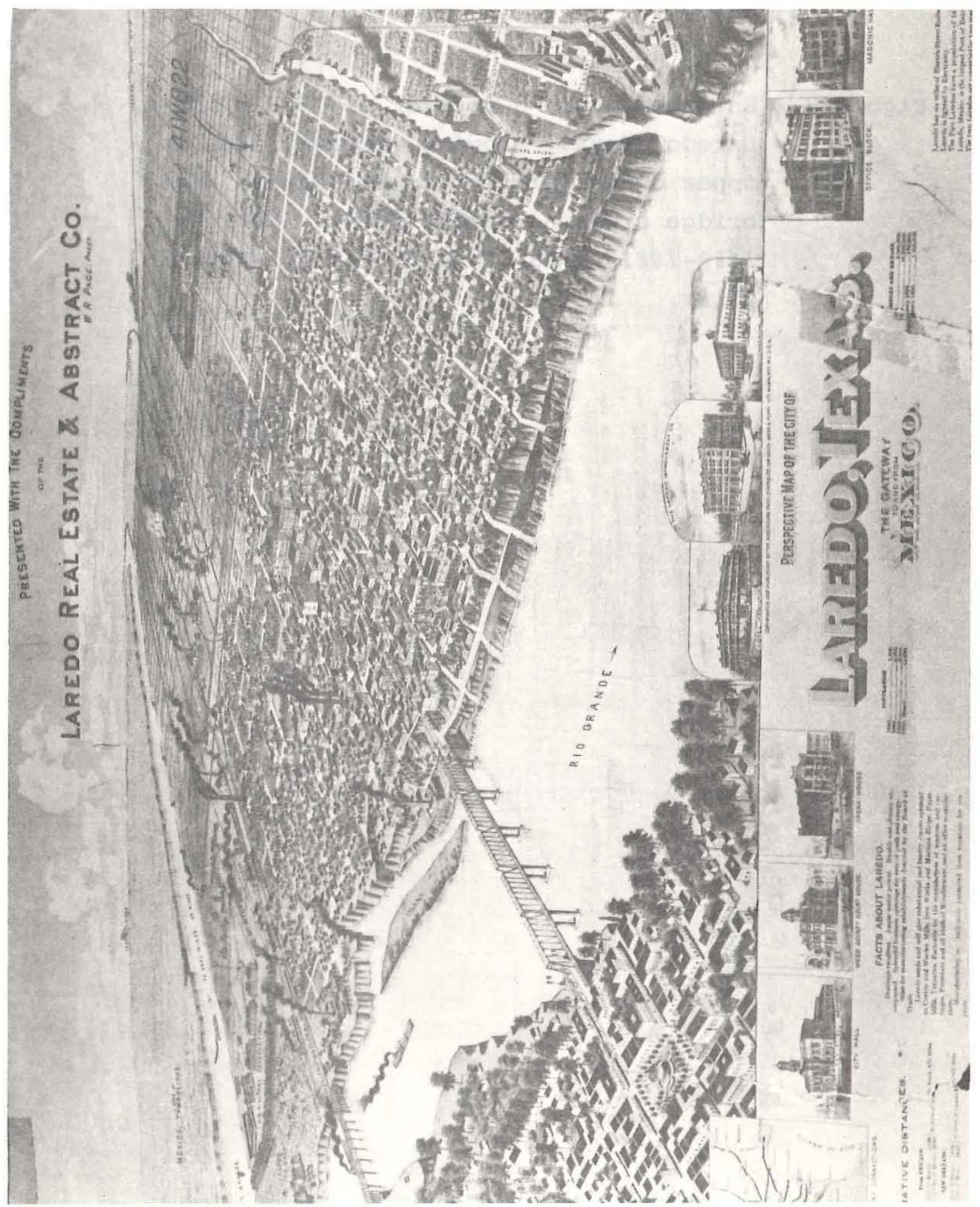


Figure 3. Enlargement of a portion of 1890's map of Laredo, Texas, showing cemetery area in upper center portion of photograph near bridge crossing Zacate Creek. Source: 1920-1921 Laredo City Directory (Foster 1918). 
Figure 3

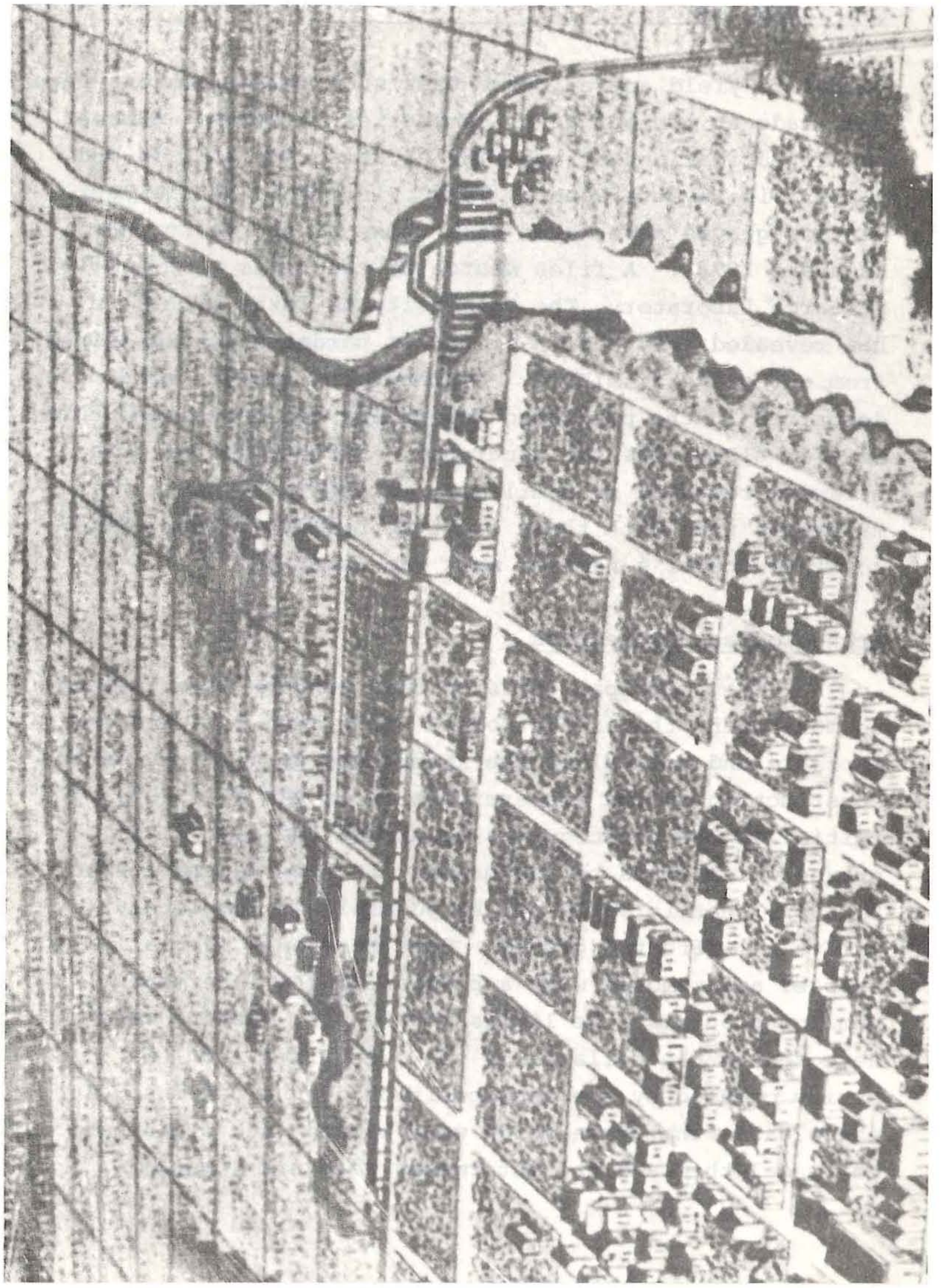


failed to yield any evidence that such investigations have been made at nonaboriginal cemeteries in Texas. However, the investigations of two 1850's farmsteads (41FY94 and 4lFy95) in Fayette County, Texas, included the disinterment of graves associated with these sites (Carter and Ragsdale 1976). A files search at the Texas Archeological Research Laboratory, The University of Texas at Austin, has revealed that coffin or casket hardware was recovered from one grave at 4lFY94. Disinterment results were not described in the published report and the associated hardware at 41FY94 was not mentioned. Examination of this hardware revealed no similarity in regard to style or materials used with those from the Laredo Cemetery site; no manufacturer's name or mark was observed.

\section{Archeological Procedures}

The principal goals of this project were limited to monitoring the excavation of eight deep pits and the exposure and removal of the interments as a result of the construction on the eastern portion of the site (Fig. 4). Initially, the strategy was to expose and remove all graves which would be disturbed. It soon became evident, however, that it would not be possible to completely remove all affected graves. Some were only partially exposed and removed with a portion of the interment remaining outside the limits of the pit. Others were detected by the collapse of the overburden into the cavity created by the decomposition of the remains. In these cases the grave voids were packed with clean sand to reseal them and the interments were not exhumed. 


\section{the laredo cemetery site}

4 I WB 22

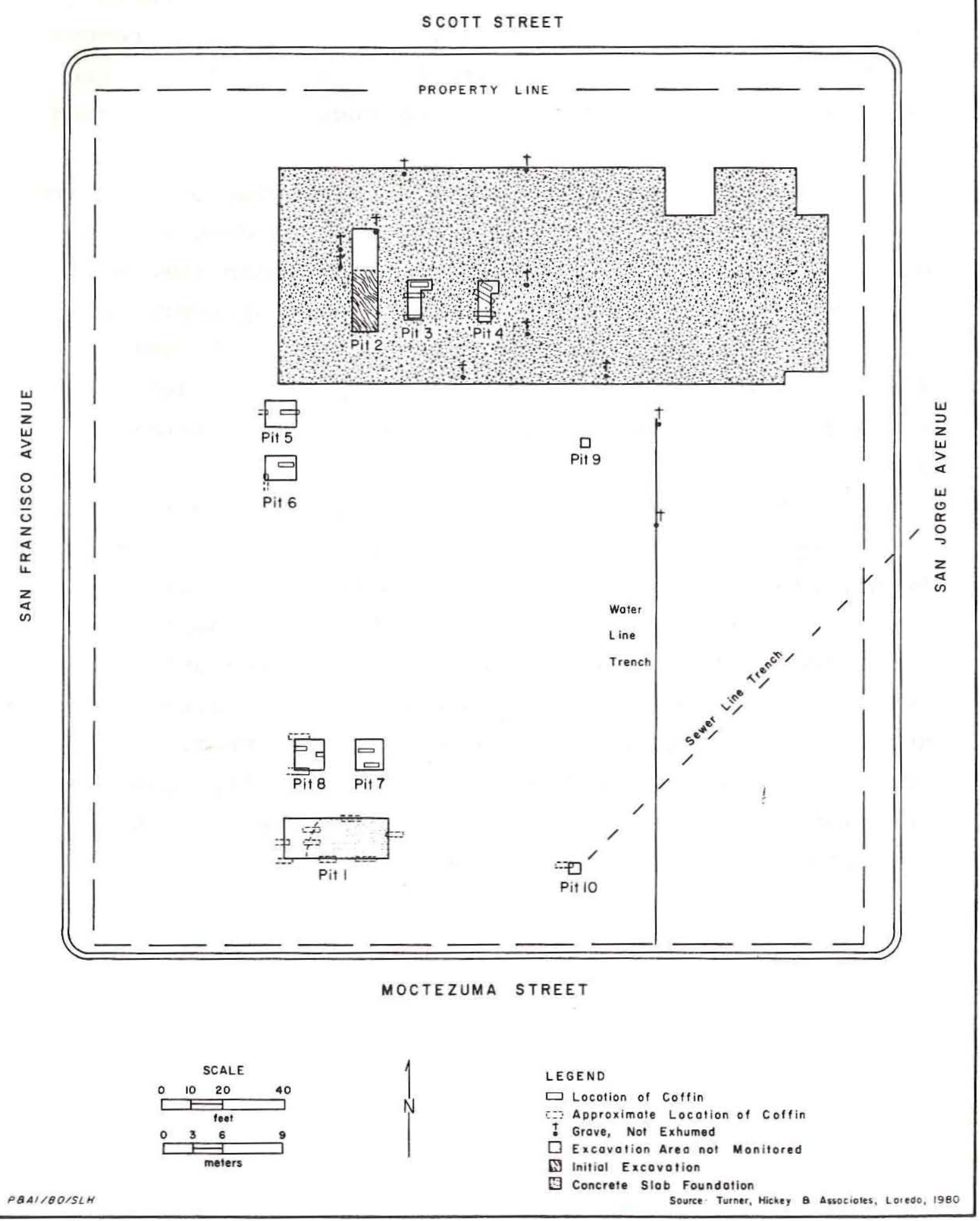


Pits were numbered in the order in which they were excavated; interments were individually numbered within each pit (i.e., Grave 1-2). Recording and removal commenced with the graves which had been exposed in the foundation area in order that construction could proceed without undue delay.

Documentation of the graves consisted of standard archeological procedures including written descriptions, measured drawings and photographs. The human remains were boxed individually by grave and were appropriately labeled. All artifacts recovered during the investigations will be reburied with the appropriate skeletal remains when the city of Laredo reinters the exhumed individuals.

At the completion of our fieldwork, the locations of thirty-six graves had been identified at the site. Twenty-two of these graves, containing a total of twentythree individuals, were either partially or completely excavated while thirteen graves were resealed and were not exhumed. One grave was completely disinterred and destroyed prior to the archeological monitoring. The remainder of this report is directed primarily toward a descriptive treatment of the exhumed remains and the accompanying cultural materials. 
Pit 1

Graves 1-1 through 1-5 were initially. exposed and partially destroyed by the backhoe and then were further disturbed by curious neighborhood residents; these graves were recorded as completely as possible and the remaining contents were examined and removed (Fig. 6).

Grave 1-1 located in the north wall is oriented east-west with the head to the west; it lies approximately 6 feet below the present ground surface. Only about one-third of the coffin remains in the wall of the pit. Coffin length is 86 inches and the depth is 11.5 inches; the disturbed state of the interment precluded determination of the width. The truncated diamond style coffin* is constructed of wood and nails (Fig. 5). A wood sample was collected; no hardware or ornaments were observed on the coffin. The only skeletal materials remaining were a few unidentifiable fragments.

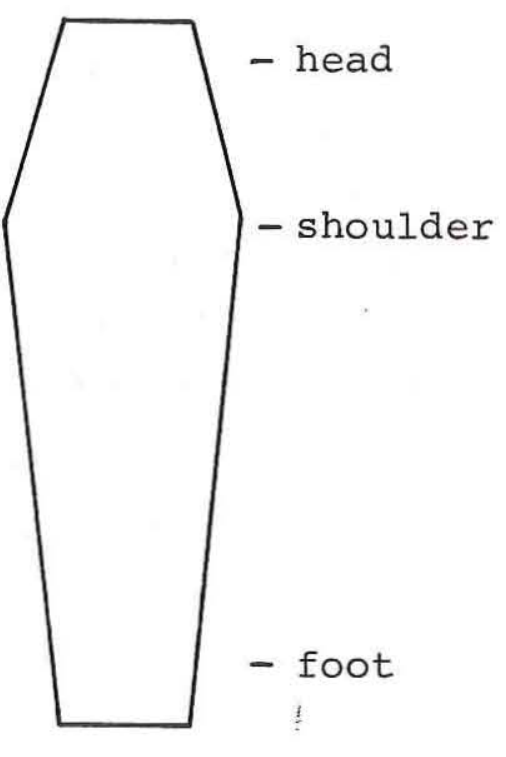

Figure 5.

Truncated Diamond

Style Coffin

*The truncated diamond style coffin is hexagonal in shape and tapers out from the head to shoulders area then tapers in to the foot area. All of the truncated diamond style coffins observed at this site were constructed using nails and wood. 
Grave 1-2 located in the east wall is oriented east-west with the head to the west. Approximately onefourth of the coffin and skeleton was removed during backhoe excavations. The remainder of the coffin collapsed and it was not possible to examine the portion which extends into the east wall of the pit. The coffin lies approximately 6 feet below the present ground surface; it is 18 inches wide at the shoulder. The depth and length of the coffin could not be determined.

The coffin is a truncated diamond shape and is constructed of wood; a sample of wood was collected. No hardware or ornaments were observed on the visible portion of the coffin. The only skeletal materials retrieved were the left humerus and assorted unidentifiable fragments; the position of the bones indicates the body is fully extended and face up.

Grave 1-3 located in the south wall is oriented east-west with the head to the west and lies approximately 6 feet below the present ground surface. The backhoe excavations disrupted relatively little of the coffin itself; most of the damage was due to the sub-: sequent collapse of soft overburden which composes the grave fill.

The coffin is 66.5 inches long, approximately 8.5 inches wide at the foot, and approximately 9 inches deep. It is constructed of wood in the truncated diamond style; a wood sample was collected. No hardware was observed. Skeletal remains recovered include the legs and feet of this individual. The collapse of grave fill sealed the remaining portion of the skeleton. The 


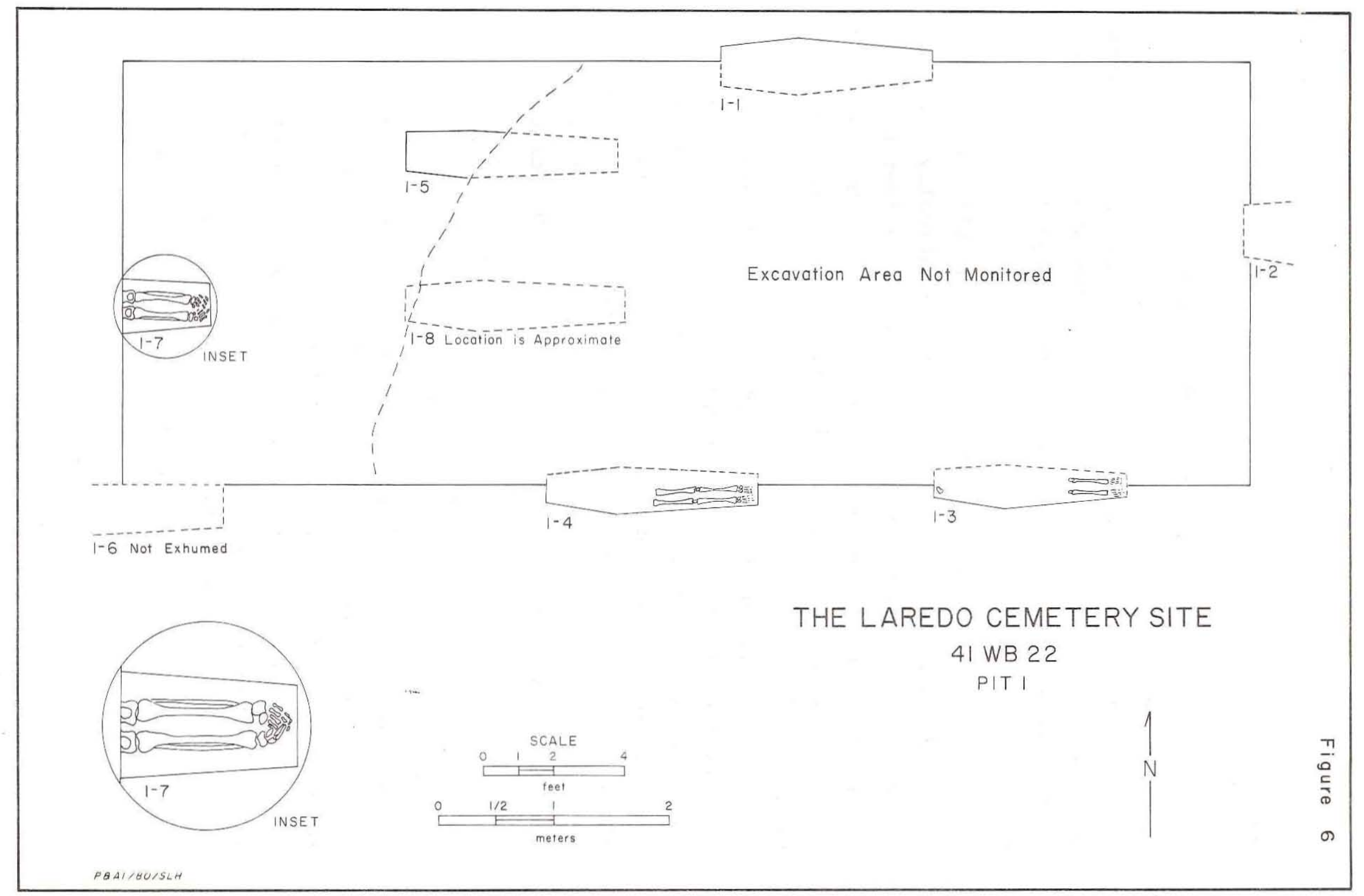


position of the feet and legs indicates the skeleton lies fully extended, face up.

Personal effects associated with Grave 1-3 include the remnants of a pair of leather high top shoes with onehalf-inch heels; this type of footwear suggests that probably this individual is a female.

Grave 1-4 is located in the south wall approximately 5 feet directly west of, and oriented identically with, Grave 1-3. The coffin rests approximately 6 feet below the present ground surface and is 73 inches long, 10 inches wide at the head, 11 inches wide at the foot, and approximately 10 inches deep.

The coffin is a truncated diamond in form and is constructed of wood; a wood sample was collected. No hardware was observed. The sparse skeletal materials present include the legs and feet of this individual; these were observed within the collapsed eastern portion of the coffin. The position of the legs and feet indicate the skeleton lies fully extended, face up. No personal effects were recovered from Grave 1-4.

Grave 1-5 located in the west wall is oriented east-west with the head to the west. Over one-half of the coffin was removed by the backhoe, and the section extending into the west wall has collapsed (much like Grave 1-2); only traces of the interment are visible. A small fragment of a skull was recovered; this provides an indication of the orientation of this individual. A wood sample was collected from the casket remains.

Grave 1-6 is located in the south wall and is oriented east-west. The north wall of the coffin is 
partially exposed but the contents were not exhumed; this interment was resealed rather than removed.

Grave 1-7 extends from the west wall of the pit and is partially exposed. Oriented east-west with the head to the west, the coffin lies 4 feet below the present ground surface. It is 18 inches wide at the foot and is approximately the same width where the wall of the pit intersects the coffin. The exposed length of the coffin is 27 inches and it is 9 inches deep.

The truncated diamond style coffin is constructed of wood; a sample was collected. Hardware* recovered from the coffin consists of two metal handles, one screw plate with thumbscrews, and two studs (Fig. 7). The handles, one from either side, were cast of zinc alloy, were plated with nickel, and were attached to the coffin with iron screws; the heads of these were also probably plated with nickel. Two different numbers appear; one is on the handle proper and one is on the attachment pieces or ears. The design of the handles is ornate; leaves and vines fill the rectangular attachment pieces and also appear on either side of a pair of clasped hands which are centered on the handle.

The screw plates with thumbscrews consist of an iron screw with a cast decorative head. This piece was cast of zinc alloy and plated with nickel; it is decorated with a vine which winds into the four corners of a diamond-shaped vertical piece.

The studs are stamped of a cuprous alloy and are plated with nickel. The elongated diamond is decorated with

*See the Glossary on page 65 for definitions of coffin hardware terms. 
Figure 7. Coffin hardware (actual size) from Grave 1-7.

a. Composite view of handle showing clasped hands design.

b. Screw plate, side view.

c. Stud, side and plan view. 
Figure 7
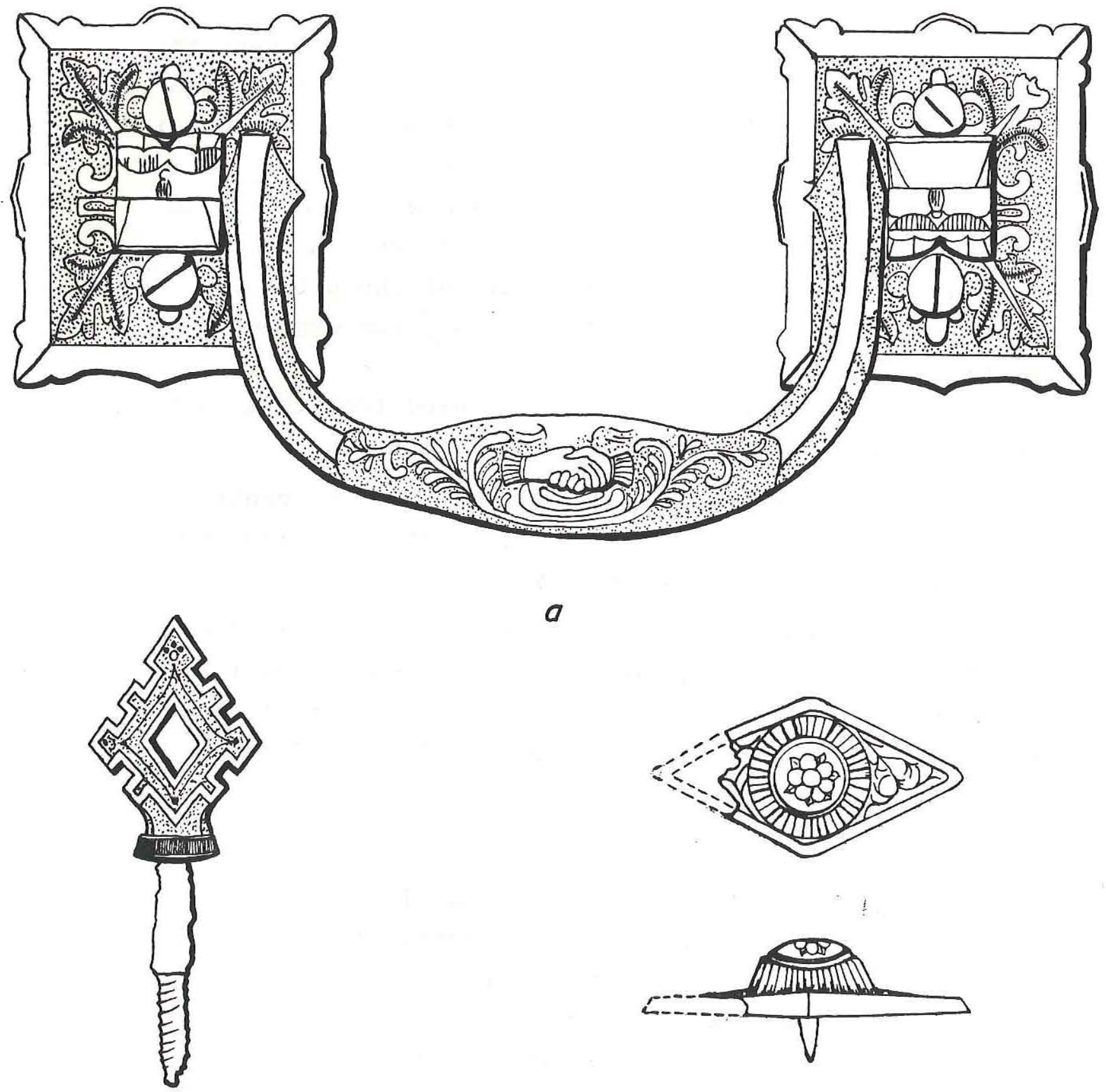

b

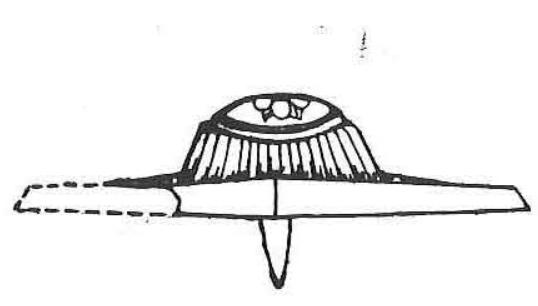

c 
a design that consists of flowers, leaves and vines; the flower appears on the top of the domed area and the flowing vines are on the flanks below. The attachment screw joins the ornament at the center of the piece.

The skeleton is fully extended with the face up and the exposed portion is articulated even though the coffin has collapsed. The west wall of the pit intersects the skeleton at the patella; only the exposed portions were collected.

The cultural materials recovered from this interment consist of two fragmentary metal buttons.

Grave 1-8 was located somewhere in the central portion of Pit 1 and was completely removed during the initial backhoe excavations (Paiz 1980).

It is not known whether other graves were located in the center of Pit 1 ; however, the alignment of the recorded interments suggests the possibility that another grave could have been located between Grave 1-1 and Grave 1-3.

Pit 2

Pit 2 is located in the foundation area on the north side of the site and was excavated to a depth of 6 feet 2 inches without encountering any interments. The varying depths of the graves uncovered in the adjacent Pits 3 and 4 suggest it is possible that a grave or graves probably lie within the limits of this pit. No anomalies were observed, however, when the floor was probed. The lack of visible grave outlines may be explained in part by the presence of 10 to 12 inches of foundation fill which was introduced on the surface prior to excavation of the pit. 
Pit 3

Pit 3 contains the remains of three individuals; one was completely exposed and removed while two were only partially exposed and removed (Fig. 8).

Grave 3-1 located in the northern portion of the pit is oriented east-west with the head to the west. This interment was completely exposed with the exception of the extreme west end of the coffin. The coffins rests 6 feet below the present ground surface; it is 68 inches long, 13.5 inches wide at the head, 20 inches wide at the shoulder, 10 inches wide at the foot, and 6 inches deep. The coffin is a truncated diamond in shape and is constructed of wood; a wood sample was collected. No hardware was found.

The skeletal remains are disarticulated. Some of the displacement may be due to the collapsed condition of the coffin; however, the position, appearance and state of preservation of this individual indicates other serious disturbance.

The depth of the remains within the coffin varies from 0 (the collapsed lid of the coffin) to 6 inches (the bottom of the coffin). The skull, in two pieces, rests 6 to 8 inches from the west end (or top) of the coffin and approximately 2 inches below the lid; the mandible is in two pieces and rests under the pelvis. The pelvis lies under the left femur and is at the lower end of the coffin. The pelvis, left femur, ribs, vertebrae, metatarsals and humerus are at approximately the same depth and are scattered throughout the lower half (foot) of the coffin. Preservation is extremely poor and the bones disintegrated even further upon exposure. 
It is difficult to explain the disarticulated state of this interment. It appears this individual was buried in a fully extended face-up position; however, the absence of some of the skeletal parts and the disarticulation of the extant remains do not appear to be the result of simple decay and coffin collapse. Rather, it appears the circumstances at the time of death, including the cause of death and the place of death (possibly a place other than Laredo), are the factors which may have contributed to the disarticulated state of the skeletal remains. It is probable that this grave represents a reburial of this individual.

The personal effects associated with Grave 3-1 include four 5/8-inch cloth-covered buttons, one 3/8inch navy blue glass button, and six black jet or glass buttons varying in size (3/8 inch to $7 / 16$ inch) and in style (two- and four-hole). All the buttons were recovered from the upper torso area and may indicate the presence of a shirt and vest.

Grave 3-2 is oriented east-west with the head to the west; it is only partially exposed in the east and west walls of Pit 3. The coffin lies 7 feet 6 inches, to 8 feet 3 inches, head and foot respectively, below the present ground surface and is 33.5 inches south of Grave 3-1. The width of the coffin at the intersection with the west wall is 18 inches, and it is 12 inches wide at the intersection with the east wall. It was not possible to determine the depth of the coffin.

The truncated diamond coffin is constructed of wood; a sample of the wood was collected. No hardware was found with the collapsed coffin. The skeleton is 
THE LAREDO CEMETERY SITE

41 WB 22

PIT 3

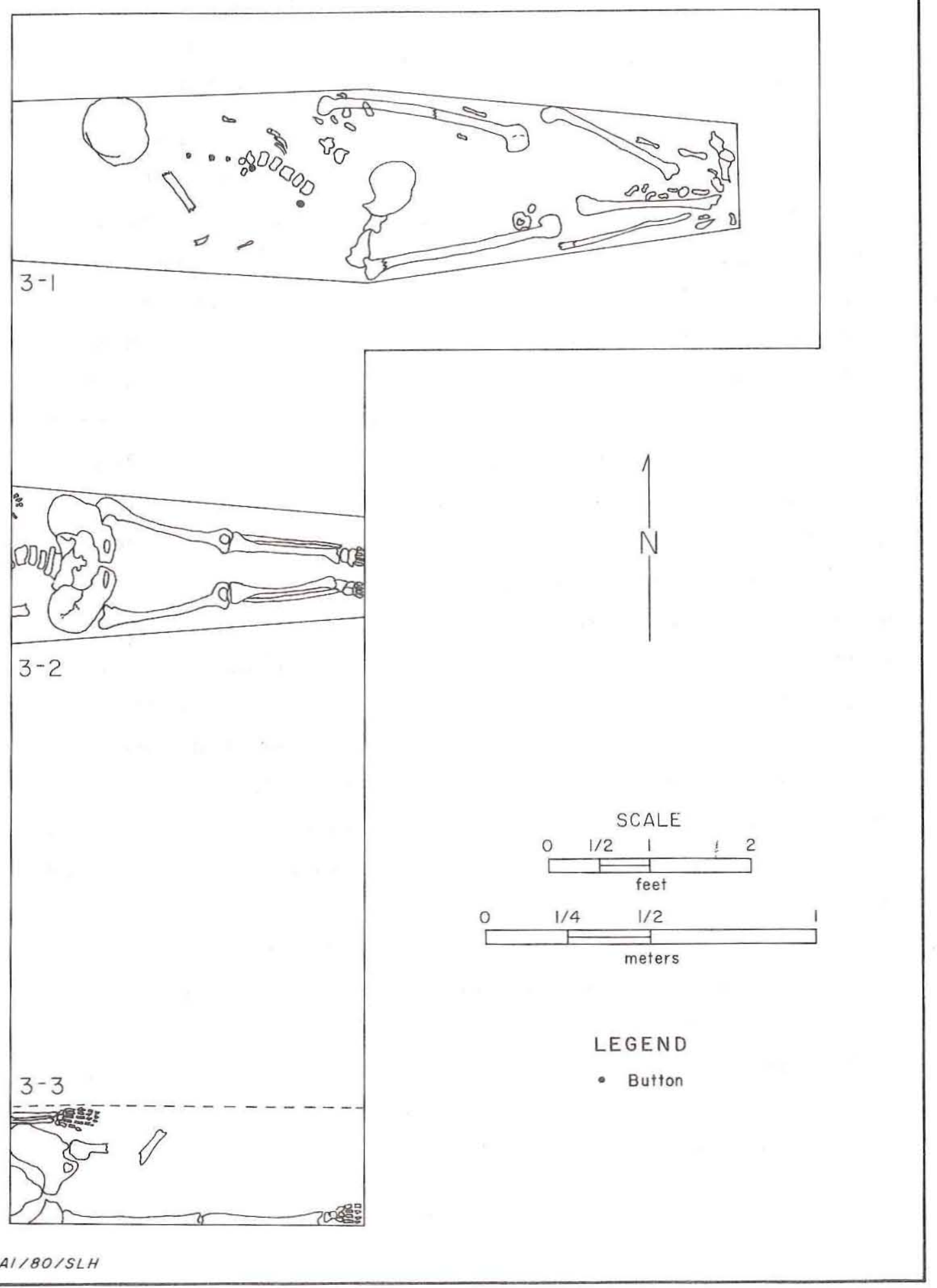


fully extended, face up, and the exposed portion is articulated. The bones are fairly well preserved.

The only personal effect associated with Grave 3-2 is a fragment of coarsely woven black fabric.

Grave 3-3, oriented east west with the head to the west, is partially exposed at the intersection of the east, south and west walls of Pit 3 . The coffin is 6 feet 7 inches below the present ground surface and is 55 inches south of Grave 3-2. The coffin is 14 inches wide at the intersection of the west wall and is 6.5 inches deep. It is not possible to determine the width at the intersection of the east wall; when removing the overburden from this interment, the backhoe inadvertently cut into the coffin, partially removed the left side of the coffin, and disassociated the left leg and foot.

Only a relatively small portion of the coffin was excavated due to the extenuating circumstances noted above, and it was not possible to ascertain if the coffin is truncated. However, since all other interments recorded at this site are of the truncated diamond style of coffin, it is reasonable to assume this one is of the same style. The coffin is constructed of wood, and a sample was collected. No hardware was recovered from this grave.

The skeleton is fully extended with the face up and with the exception of the disassociated portion described above, it is relatively well articulated. The west wall of the pit intersects the skeleton at the pelvis, which is partially crushed due to the collapse of the coffin. 
The only personal effects associated with Grave 3-3 are the remains of an unidentified white fabric observed adhering to the pelvis and legs. The fabric appears to have been very thin and finely woven; however, only the impression of the fabric remains and it was not possible to collect a sample.

\section{Pit 4}

Pit 4 contains the remains of three individuals; one was completely exposed and removed while two were partially exposed and removed (Fig. 9).

Grave 4-1 is fully exposed in the northern extremities of the pit. This interment is unique for several reasons: (1) it is the only singly intered subadult; (2) the orientation of the coffin is noticeably dissimilar from the customary east-west orientation; (3) the construction style of the coffin varies from that of the other coffins; and (4) a relatively large quantity of hardware is associated with the coffin.

The coffin rests 1 inch and 8 inches (head and foot respectively) south of the north wall of the pit; this orientation is approximately $20^{\circ}$ north of the! eastwest alignment which appears to be the preferred rule at this site. The head is to the west. The coffin lies only 5 feet 7 inches below the present ground surface; it is 40 inches long, approximately 4 inches wide at the head, 11 inches wide at the widest point, 7 inches wide at the foot, and 8 inches deep.

Although it is constructed in the basic truncated diamond style, this coffin varies from those previously 
described. This may be due to the fact that it was intended for a child, but it also is at variance in the quality of style or design. The coffin does not exhibit sharp corners at either end and the shoulder lacks sharply defined angles. The top or head is rounded and expands from 4 inches to 11 inches at the shoulder then subtly tapers to 7 inches at the foot. The edges of the lid and body of the coffin are rounded and resemble moulding. The exterior is covered with a light yellowish-tan paint; a sample of the wood was collected.

The hardware associated with this coffin includes four metal handles, three screw plates with thumbscrews and four studs (Fig. 10). Two handles which are cast of zinc alloy and plated with nickel were located on each side of the coffin. They were attached with iron screws, the heads of which were also plated with nickel. The design on the heads is a relatively simple leaf-and-vine motif. A style or cast number appears on the back of the handles.

Three screw plates with thumbscrews were recovered from the collapsed lid of the coffin; the heads of zinc alloy were cast directly onto the iron screw and are plated with nickel. The diamond-shaped vertical piece decorated with three small flowers is perpendicular to an oblong horizontal piece which is decorated with leaves and flowers and incorporates the head of the attachment stud into the design. The manufacturer's name, a date, and a style number appear on the reverse side of this piece.

One stud stamped of cuprous alloy and plated with nickel bears a design that includes grapes, vines and 


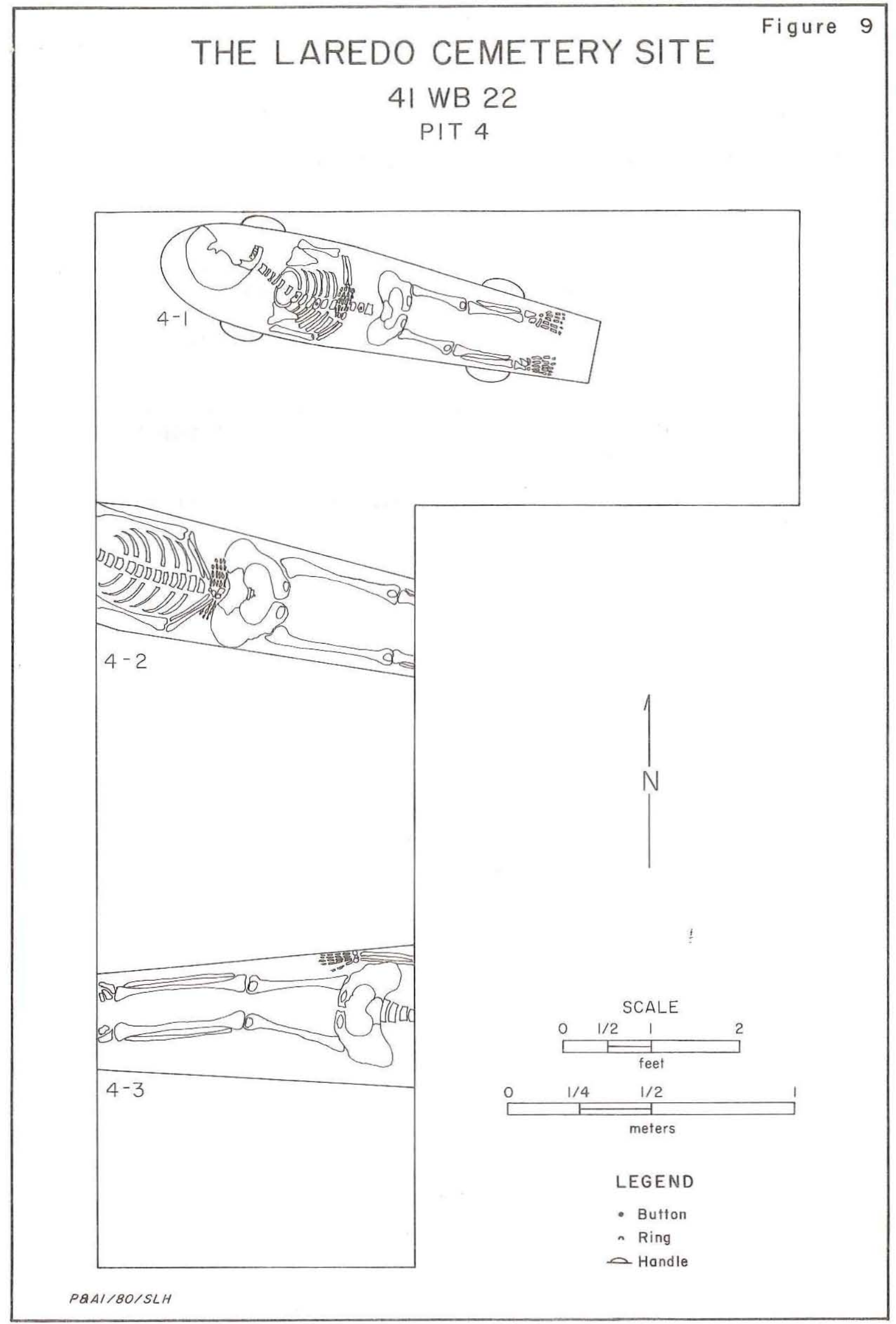


Figure 10. Coffin hardware (actual size) from Graves 4-1 and 5-1.

a. Grave 4-1, composite view of handle showing design on handle and ear pieces.

$b, c, d$. Grave 4-1, three styles of decorative studs, plan view.

e. Grave 4-1, screw plate with thumbscrew, plan view, reverse, and detail of top portion of the thumbscrew.

f. Grave 5-1, thumbscrew, side and plan view. 
Figure 10

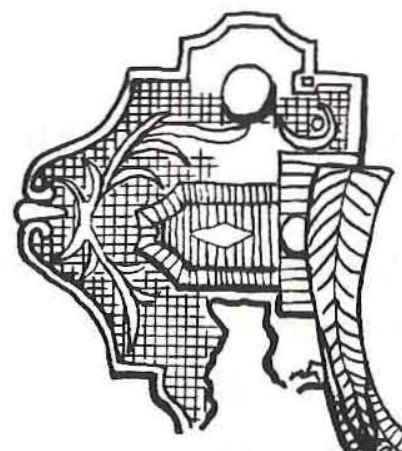

(2)
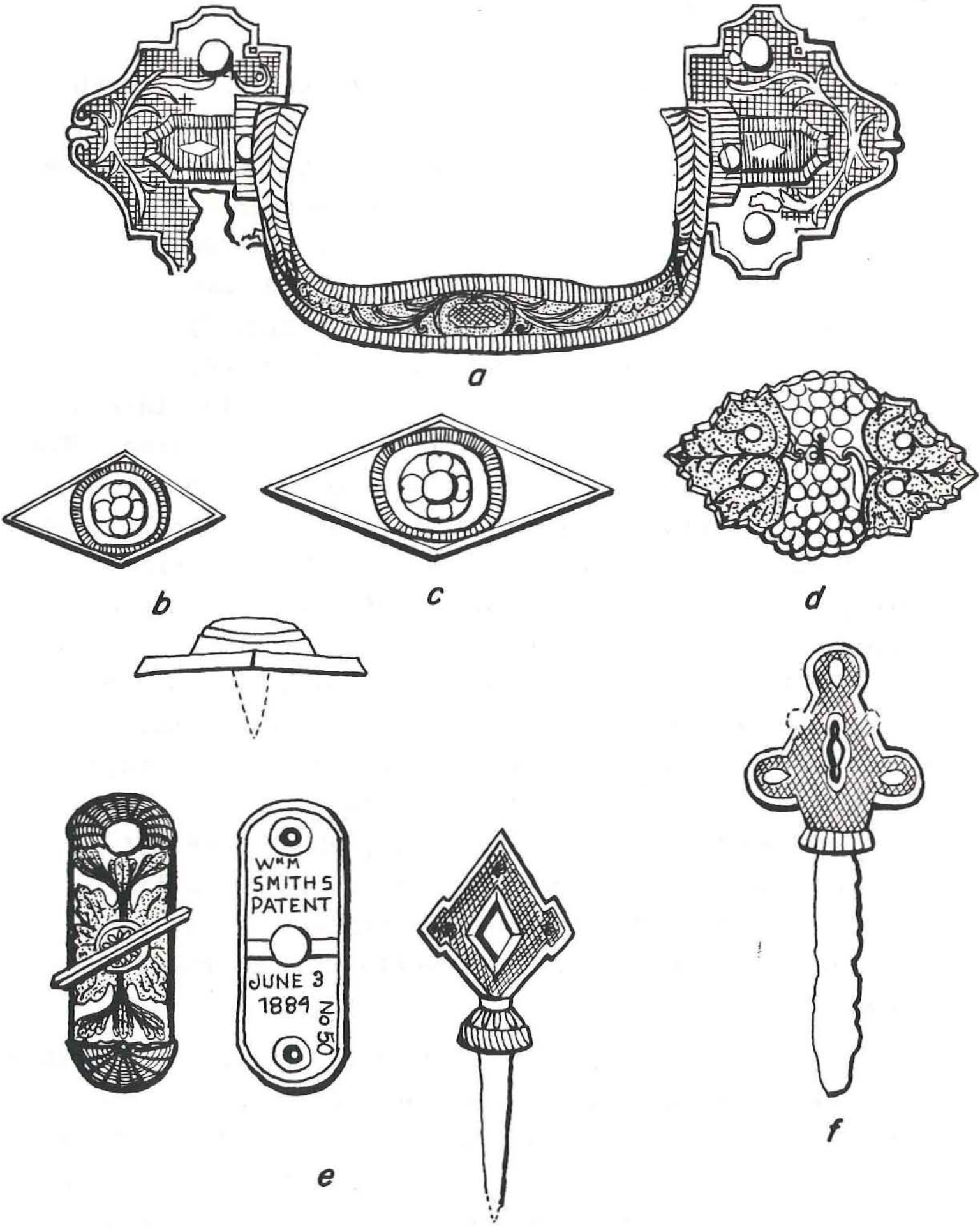
leaves. This ornament was attached to the coffin with an iron nail or screw.

The other two studs were also stamped of cuprous alloy and plated with nickel and were attached to the coffin in the same manner as the other. The design on these ornaments is almost identical to the same style ornaments recovered from Grave 1-7 (see Fig. 7). Note that two sizes of this ornament were recovered.

The skeleton is fully extended with the face up and with the arms crossed over the lower chest area. The remains are articulated except for the skull which was crushed under the weight of the overburden and collapsed lid of the coffin. No deformities or abnormalities were observed. Tufts of coarse black hair cling to the skull fragments. Preservation of the skeletal materials is good. This skeleton is accompanied by a ring which was recovered from the fourth finger of the left hand. Also recovered were varying lengths of twisted metal fragments which were intertwined with the tufts of hair on the skull fragments. These are possibly the remains of some type of bonnet or cap which was placed on the child's head at the time of burial. Four white 5/8-inch porcelain buttons were recovered from directly beneath the spinal column.

Grave 4-2 is partially exposed within Pit 4. This interment is located 24 inches south of and at the same angle and direction of orientation as Grave 4-1. However, Grave 4-2 rests 6 feet 9 inches below the present ground surface and is 14 inches deeper than Grave 4-1. Although a common (family) plot is inferred, the variance in depth of interment could indicate differing times of death. The 
coffin is 13 inches wide at its intersection with the east wall, 20 inches wide at its intersection with the west wall, and 8 inches deep.

The collapsed coffin is a truncated diamond style and is constructed of wood and nails; a wood sample was collected. No hardware was observed.

The skeleton lies fully extended, face up, and with the arms crossed over the abdomen. The east and west walls of the pit intersect the skeleton at the tibia-fibula and clavicle respectively. No abnormalities or deformities were noted; however, the remains are poorly preserved and resulted in fragmentation of the bones upon removal.

Personal effects associated with this interment include one 3/8-inch white porcelain button recovered from the chest area, three 3/4-inch fragmented metal buttons with cloth adhering to them (cloth covered?), one 11/16inch blue-stained wooden button, one 3/4-inch white shell button, and a fabric fragment of coarse brown closed-weave cloth similar to the fragments observed on the metal buttons. A ring was recovered from the fourth finger of the right hand.

Grave 4-3 is partially exposed in the south end of the pit and is oriented east-west with the head to the east. The east and west walls intersect the coffin 24 inches and 27 inches respectively from the south wall of the pit, and 49 inches and 64 inches respectively from Grave 4-2. The coffin rests 6 feet 8 inches below the present ground surface; it is 20 inches wide at the intersection of the east wall, 13 inches wide at the intersection of the west wall, and is 7.5 inches deep. 
The coffin is a truncated diamond style and is constructed of wood; a wood sample was collected. No hardware or ornaments were recovered other than iron nails used in the construction and sealing of the coffin. The coffin is collapsed and preservation of the wood is poor.

The skeleton is fully extended, face up, and is partially disarticulated. The east wall of the pit intersects the skeleton at the third vertebra, and the west wall intersects it at the ankles. No deformities or abnormalities were observed; however, the left arm was not visible in the exposed portion of the coffin. It is possible that the left arm is crossed over the body in an unobservable position. Preservation of the remains is extremely poor.

The presence of lime scattered throughout the coffin is unique to this interment. One explanation of its presence could be to guard against contamination if disease was the cause of death.

The personal effects associated with Grave 4-3 include four 5/8-inch heavily corroded metal buttons, one 3/8-inch white porcelain button, one 5/8-inch white porcelain button, and one belt end fragment which is covered with cloth.

Pit 5

Pit 5 contains the remains of two individuals; one was completely exposed and removed while one was partially exposed and removed (Fig. 11).

Grave 5-1 is fully exposed and extends from the east wall of the pit. Oriented east-west with the head 


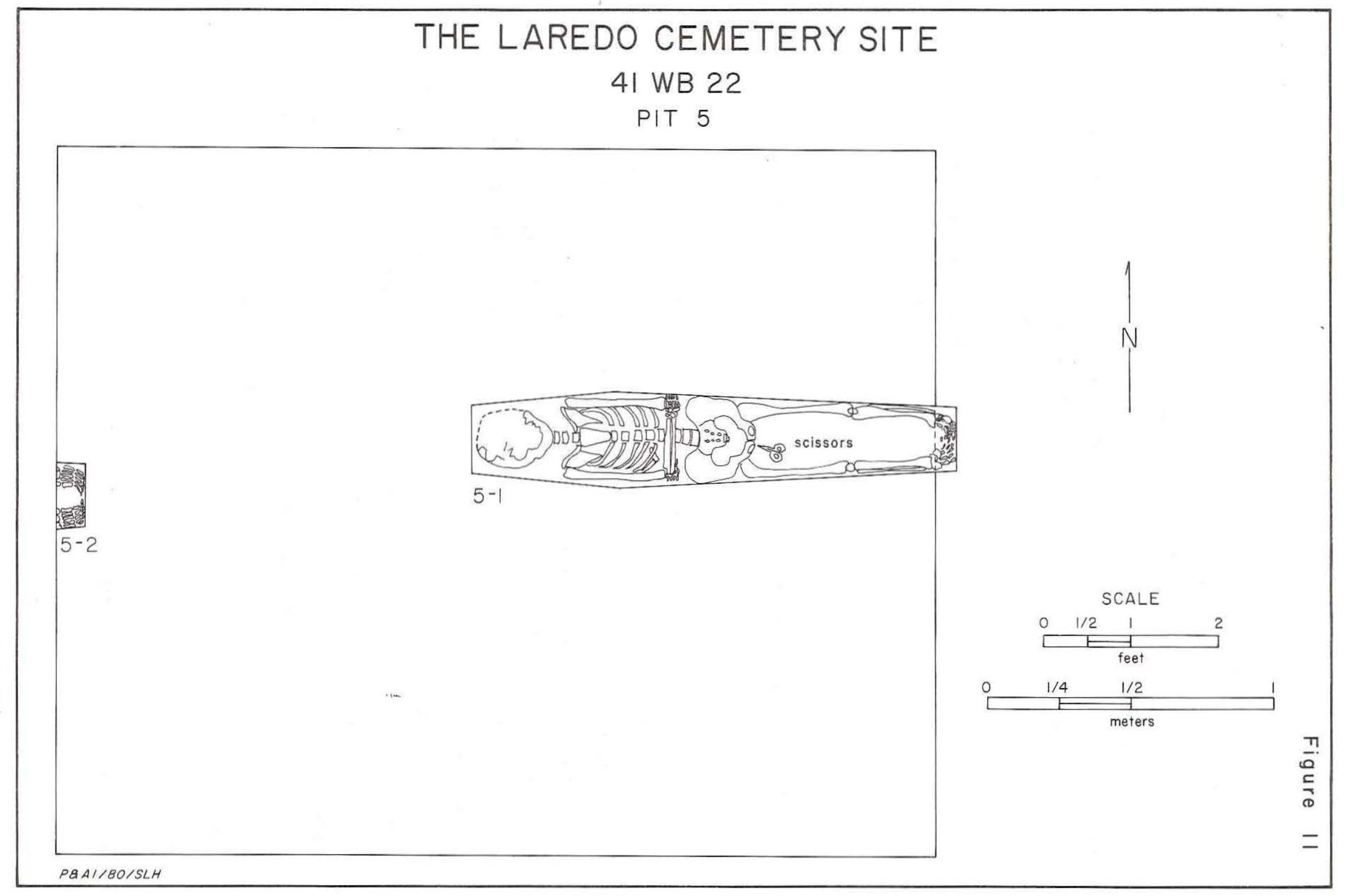


to the west, the coffin intersects the east wall with approximately 3 inches extending into that wall; however, the east wall was slightly undercut by the backhoe and it was possible to expose the entire interment. The coffin lies 6 feet 1 inch below the present ground surface; it is 65 inches long, 9 inches wide at the head, 15 inches wide at the shoulder, and 8 inches wide at the foot. The coffin is collapsed and prevents the accurate measurement of the depth.

The coffin is a truncated diamond shape and is constructed of wood; it was not possible to collect a sample of the wood due to its extremely poor state of preservation and the collapsed condition of the coffin. Hardware is present in the form of two screw plates and thumbscrews (Fig. 10). This coffin is the only example which included this item of hardware without also including handles. The style of these ornaments, which were probably positioned on the lid of the casket, is a key and/or keyhole design. The heads are cast of zinc alloy onto the iron screw which attached to the coffin and are plated with nickel.

The skeleton is fully extended, face up, with the arms crossed over the abdomen. The skeleton is partially disarticulated; this is due primarily to crushing of the skull and pelvis following the collapse of the coffin. The body apparently completely filled the coffin; this is reflected in the positioning of the feet which are crossed over each other. Preservation of the skeletal material is poor.

The personal effects associated with Grave 5-1 include several items; the most notable are a pair of 
scissors and a heavily corroded coin. The scissors are tightly wrapped in the remains of cloth and were apparently resting in an intrusive position in the lower pelvic region. It is probable that they were placed in a pocket and settled into that position following decomposition of the body. The coin was recovered from the fill of the coffin; it is unclear whether it was placed in a pocket or in the hand of the individual. The coin is a United States Liberty Head nickel minted in 1890 (Yeoman 1976: 90-91). Also recovered from Grave 5-1 were two white porcelain buttons and one 1/2-inch metal button; the latter has remnants of a heavy brown cloth adhering to the back and was probably cloth covered.

Grave 5-2 is partially exposed near the center of the west wall of the pit. Oriented east-west with the head to the west, the coffins rests 6 feet 2 inches below the present ground surface. Only 4 inches of the bottom or foot of the coffin was exposed. The coffin is 9 inches wide at the foot and the depth is 6.5 inches.

The coffin is probably a truncated diamond in style and is constructed of wood. Preservation of this collapsed portion is extremely poor; no wood sample was collected, nor was any hardware recovered from the coffin.

The skeletal remains exposed consist only of the feet; these were jammed against the end of the coffin. Preservation of the bones is fairly good, and it was possible to remove them without causing fragmentation. The position of the feet suggests this individual was buried fully extended with the face up. No cultural remains were recovered from this interment. 
Pit 6

Pit 6 contains the remains of two individuals; one was completely exposed and removed, and the other was only partially exposed and removed (Fig. 12).

Grave 6-1 is exposed in the northeast section of the pit. Oriented east-west with the head to the east, the coffin lies 6 feet below the present ground surface. The coffin is 68 inches long, 15 inches wide at the head, 9 inches wide at the foot, and 3 inches deep; the lack of depth is probably due to grave collapse and fill compaction. The coffin is a truncated diamond shape and is constructed of wood; a sample of the wood was collected. The coffin is completely collapsed and the fill is compacted; no hardware was observed.

The skeleton is fully extended, face up, with the arms crossed over the pelvic area. The coffin is thoroughly crushed; the bones in the skull, chest and pelvic areas are completely crushed as a result of the weight of the grave collapse. The bones are fragmented and exposure caused further disintegration. Numerous strands of thick reddish-brown hair are present on the skull fragments. No personal effects were recovered from Grave 6-1.

Grave 6-2 is partially exposed and extends into the south wall of Pit 6. This interment was the only one oriented north-south. The coffin lies 5 feet 2 inches below the present ground surface; it extends 26 inches from the south wall and 10 inches from the west wall. The depth of the coffin is 8 inches.

Because such a small portion of the coffin was exposed, it was not possible to ascertain whether it is 


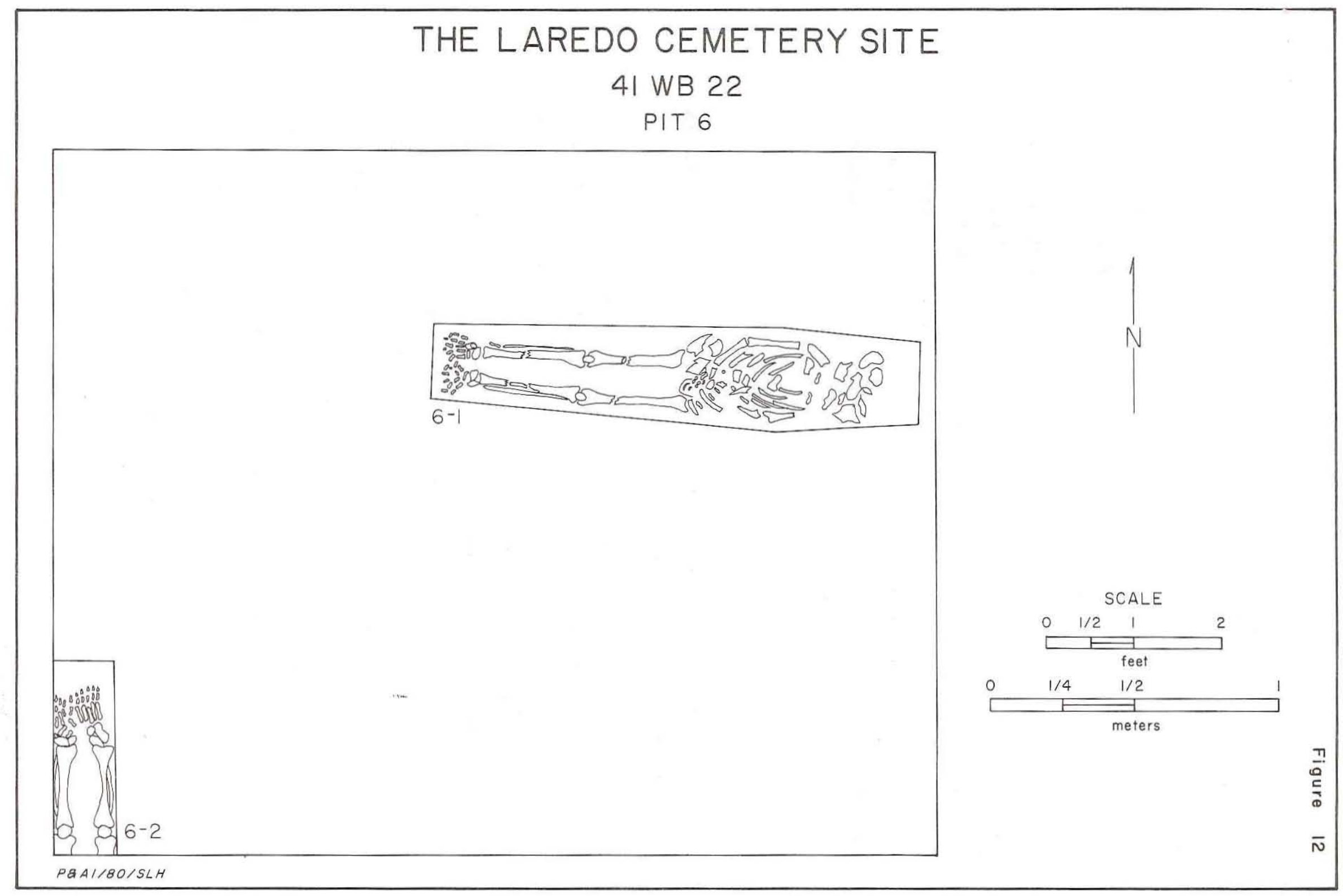


truncated. However, it is likely that such is the case; this is reinforced by the close proximity of the right leg and foot to the side of the coffin. A wood sample was collected; no hardware was observed. The skeleton appears to be fully extended with the face up; the exposed portion is well articulated. The south wall of the pit intersects the skeleton immediately above the patella; both legs and feet are exposed. No abnormalities or deformities were observed, and the preservation of the bone is fair. No cultural remains were recovered with this interment.

\section{Pit 7}

Pit 7 contains the remains of two individuals; both were completely exposed and removed (Fig. 13).

Grave 7-1 is located in the southern extremities of the pit and is oriented east-west; the head is to the east. The coffin rests 6 feet 8 inches below the present ground surface; it is 67 inches long, 9 inches wide at the head, 18 inches wide at the shoulder, 10 inches wide at the foot, and 9 inches deep.

The truncated diamond-shaped coffin is constructed of wood; a wood sample was collected. No hardware or ornaments are present on the coffin.

The skeleton is fully extended, face up, with the arms crossed over the abdomen. The remains are partially disarticulated due to the collapsed state of the coffin; the skull and chest areas are crushed. No abnormalities or deformities were observed. 


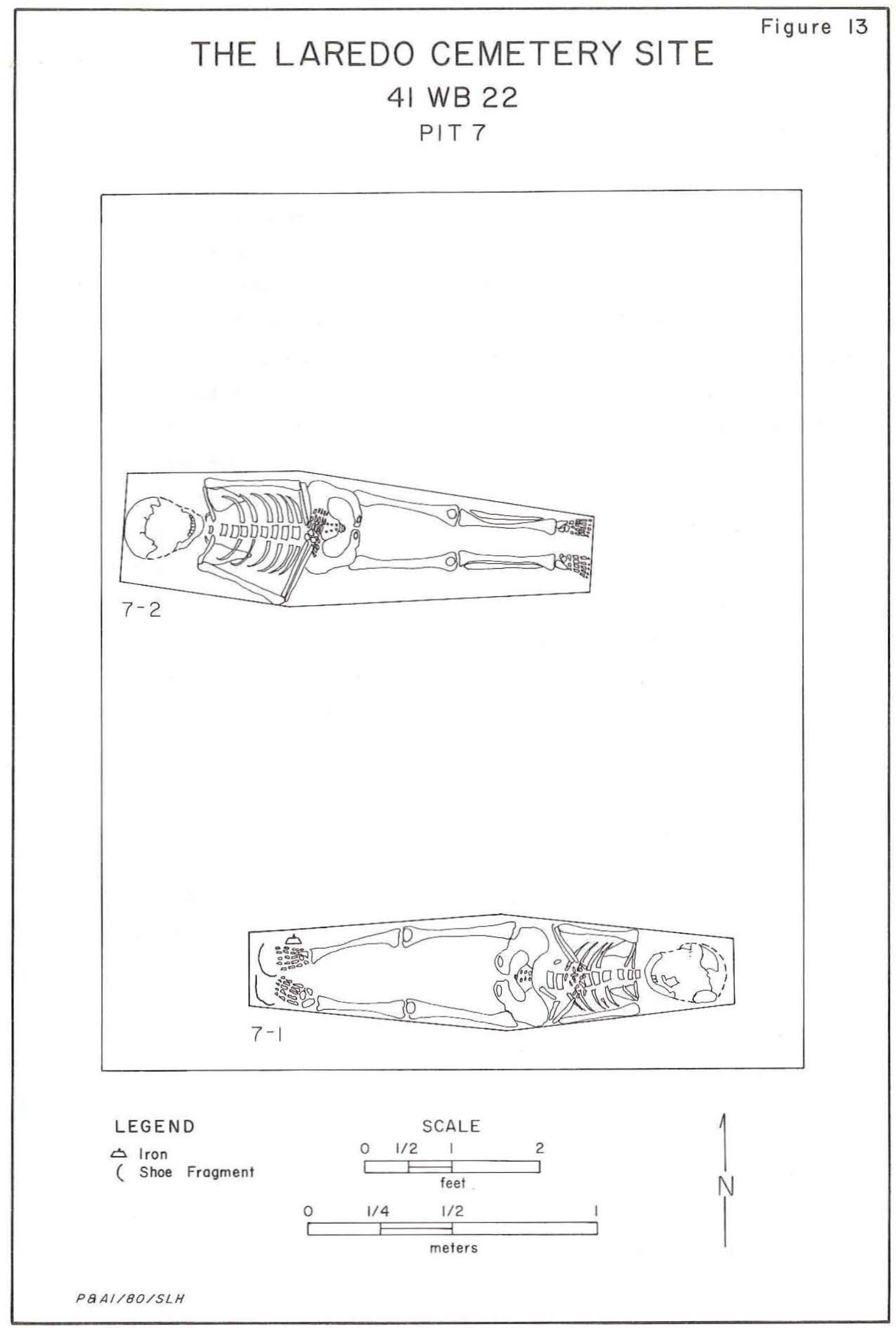


The personal effects associated with this interment include several items. The most notable of these is an 8-pound Common Pattern Sad Iron (pressing iron) (Israel 1976) which lay immediately adjacent to the right foot, pointed upward and with the handle abutting the north edge of the coffin. Centered on the top side of the iron, directly under the handle, is a keystone emblem with the number "8," indicating the weight of the iron, displayed in the center. The center section of the handle is wooden and is contoured to fit the hand. The second item of note is the remains of a pair of button- or lace-up leather ankle shoes with quarter-inch heels. The size and style of the shoes, as well as the presence of the Sad iron, indicate that the individual buried here is a woman. Also recovered were four 3/8inch black glass or jet buttons and one 3/8-inch white porcelain button.

Grave 7-2 is located approximately 41 inches north of Grave 7-1. Oriented east-west with the head to the west, the coffin lies 6 feet 8 inches below the present ground surface; it is 62 inches long, 20 inches wide at the head, 11 inches wide at the foot, and 6 inches deep.

The truncated diamond-shaped coffin is constructed of wood; a sample was collected. No hardware or ornaments are present on the coffin.

The skeleton is fully extended, face up, with the arms crossed over the abdomen. The remains are fairly well articulated except for the skull and pelvic areas which were crushed by the weight of the collapsed coffin and overburden. Preservation of the remains is 
poor; strands of thick dark brown hair remain on the skull fragments. No positive abnormalities or deformities were noted.

The only personal effect associated with Grave 7-2 was a 7/16-inch white porcelain button with a rose-colored border encircling the edge of the button.

Pit 8

Pit 8 contains the remains of four interments; three were partially exposed and removed while one was not disturbed. The latter grave was recorded and resealed without removal of the bones (Fig. 14).

Grave 8-1 located in the southwestern corner of Pit 8 is the most singular interment encountered in these excavations. Oriented east-west with the head to the east, the coffin was originally only slightly exposed. However, the backhoe unintentionally undercut the south wall, particularly the area immediately over the coffin and almost the entire width of the exposed length of 53 inches was revealed. The coffin lies 5 feet 9 inches below the present ground surface; it is 8 inches wide at the head and is 6.5 inches deep.

This truncated diamond style coffin is notable because it is painted, heavily ornamented, and the the lid contains a glass "window" over the head and chest area. The wooden part of the coffin was painted a dull red and trimmed in yellowish ivory; samples of both the wood and the paint were collected.

The hardware recovered includes four metal handles, one large metal cross, five small cross-shaped studs, two 
small wreath-shaped studs, five screw plates with thumbscrews, and one ornamental button (Figs. 15 and 16; the wreath-shaped studs and the ornamental button are not shown). The handles are cast of zinc alloy and plated with nickel. A style or cast number appears on the back of the handles. A tassel design on the two ears (attaching pieces on either end) is continuous with a cord design that winds over the handle. The space not covered with the cord motif is filled with lines and half circles.

A large cross rests on the center of the lid of the coffin; it is cast of zinc alloy and plated with nickel. The maker's name and a style or cast number appear on the back of this item of religious significance. Small holes on each end of the cross are for attachment to the coffin. The five screw plates with thumbscrews were also cast of zinc alloy and plated with nickel; a number appears on the reverse of each. A central vertical cross is flanked on either side by smaller crosses on the horizontal base piece. The center screw for attaching the ornament is made of iron; small nails or pins made of brass are located at each end.

The five small cross-shaped studs and the two wreath-shaped studs are all stamped of cuprous alloy and plated with nickel; no identifying numbers or marks were observed on these ornaments. They were attached to the coffin with small iron nails or screws.

The round ornamental button was probably covered with cloth and appears to have been part of the interior decoration of the coffin.

The most notable feature is a glass "window" in the lid of the coffin which covers the head and chest area of the body. The window is a single plate of oval- 


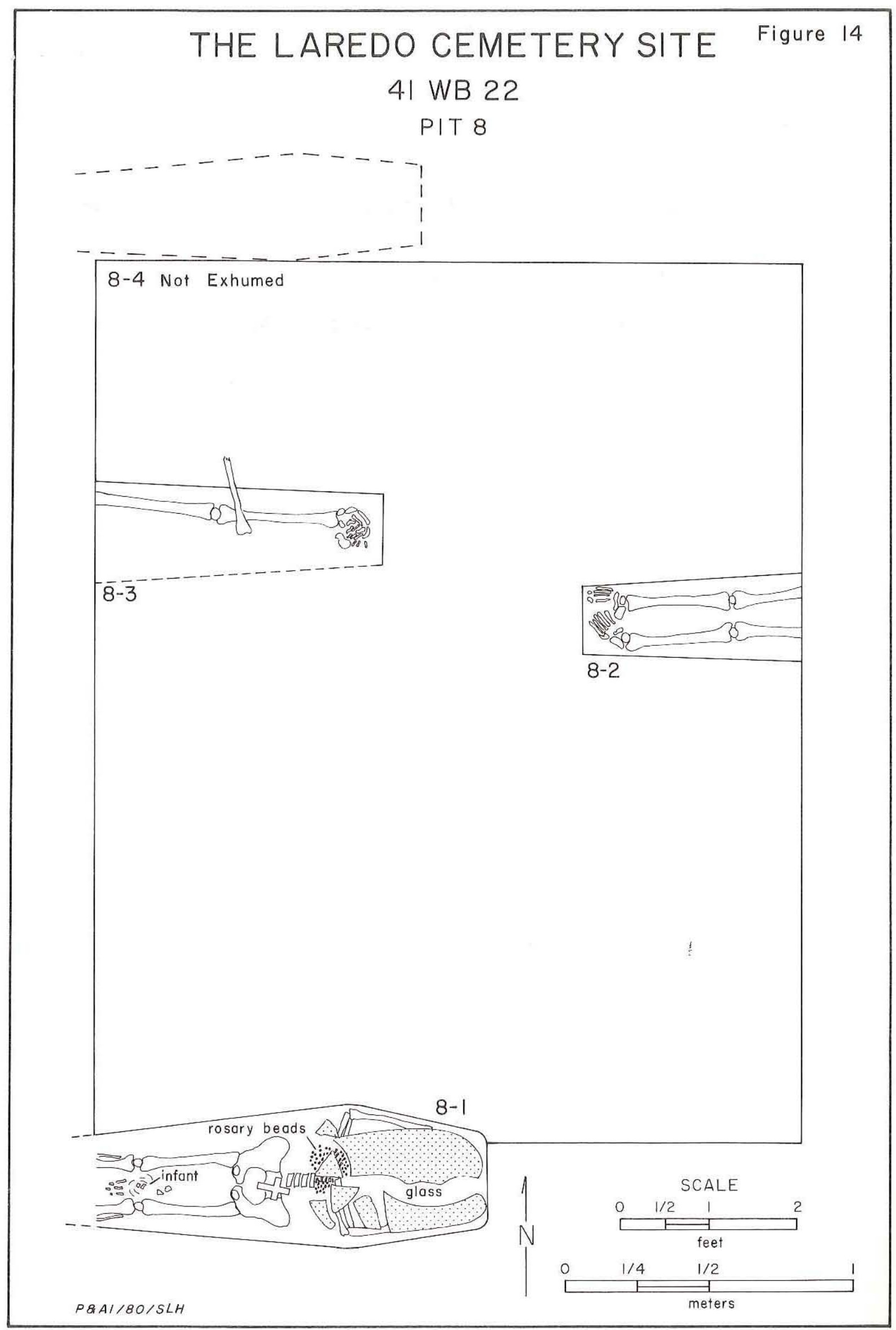


Figure 15. Coffin hardware (actual size) from Grave 8-1.
a. Handle, plan view.
b. Screw plate with thumbscrew, side and plan view.


Figure 15
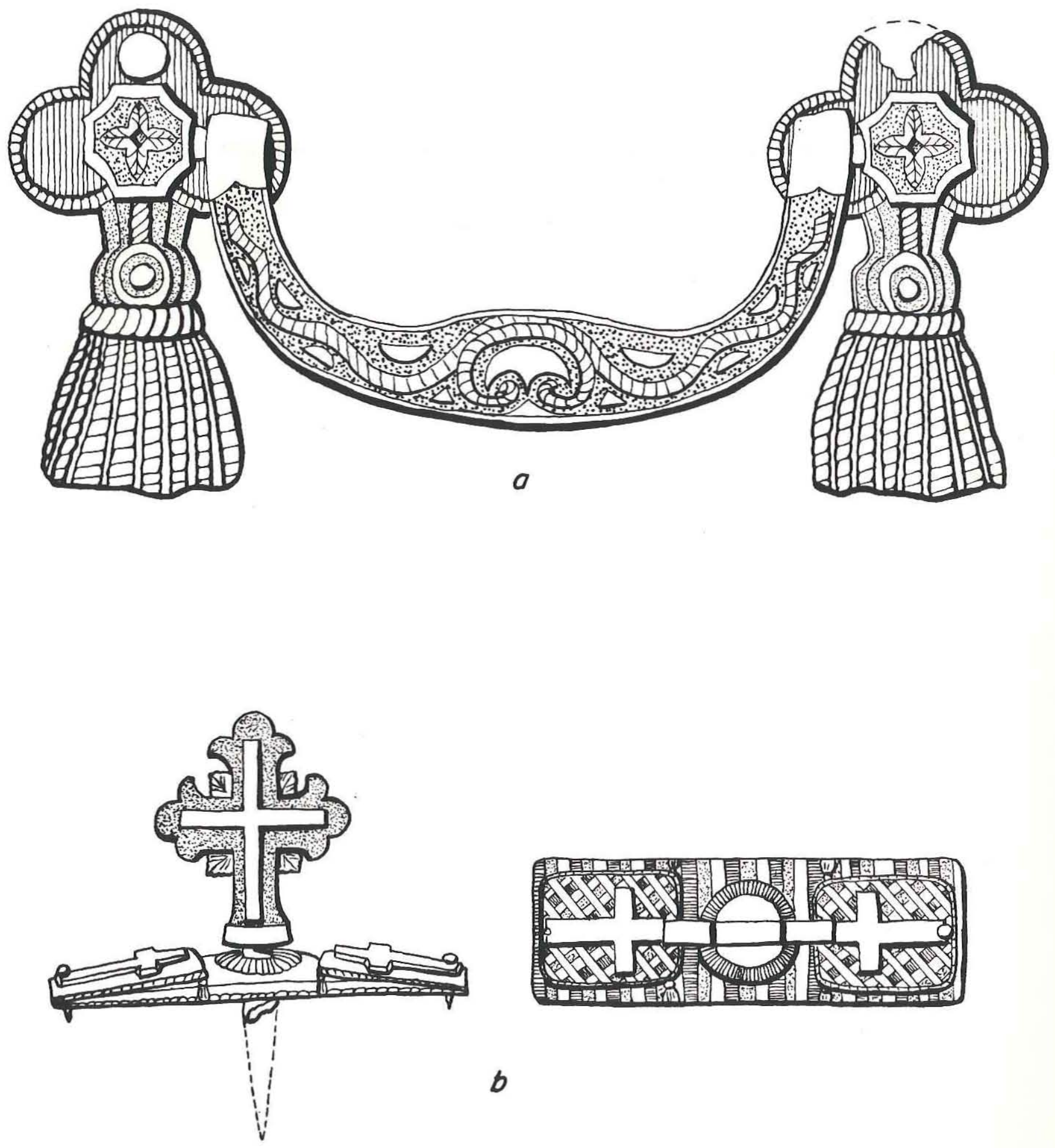

$b$ 
Figure 16. Coffin hardware (actual size) from Grave 8-1

a. Decorative ornament, plan view of front and reverse.

b. Decorative stud, plan view. 
FIGURE REDACTED

Figure 17. Grave 8-1, facing south from pit floor. Note glass fragments and cross in center of coffin. 
well articulated. No deformities or abnormalities were observed. Preservation of the bone is good.

No personal effects were recovered from this interment.

Grave 8-3 is partially exposed and extends from the west wall of Pit 8 . Oriented east-west with the head to the west, only 39 inches of the total length of the coffin are exposed within the pit. Unfortunately, while removing the overburden the backhoe cut into this grave and removed almost all of the right leg. The coffin lay 5 feet 9 inches below the present ground surface; it is 14 inches wide at the intersection with the west wall and is 4 inches deep. It is located 5 feet 10 inches north of Grave 8-1 and 30 inches west of Grave 8-2.

The truncated diamond style coffin is constructed of wood; a wood sample was collected. Four metal handles, two screw plates with thumbscrews, and one stud were recovered (Fig. 18). The handles are cast of zinc alloy and plated with nickel; they were attached to the coffin with iron screws. The heads of the screws are also probably plated with nickel. The basic style is the same as that described on the handles recovered from Grave 8-1 (see Fig. 16); however, these are more austere. A style or cast number appears on the back of the handles.

The screw plates with thumbscrews are designed in a key and keyhole style and the words "AT REST" appear on the top of the vertical piece. These pieces are also cast of zinc alloy and plated with nickel. The center attachment screw made of iron is flanked with smaller nails on each end. The maker's style or cast number appears on the reverse side. 
The stud is stamped of cuprous alloy and no identifying numbers or marks were observed. The dome-shaped "cap" conceals an iron attachment nail or screw in the center.

The skeletal remains are badly disarticulated due to the disturbance by the backhoe; however, the bone is in a fairly good state of preservation. The west wall intersects the skeleton immediately below the head of the femur. The skeleton lies fully extended with the face up; no abnormalities were observed.

No personal effects were recovered from Grave 8-3.

Grave $8-4$ in the north wall of Pit 8 was only slightly exposed and was not exhumed; it was resealed with no further investigations. 
Figure 18. Coffin hardware (actual size) from Grave 8-3.

a. Handle, plan view.

b. Decorative stud, plan view.

c. Screw plate with thumbscrew, side view.

d. Screw plate with thumbscrew, side view showing design on top portion of thumbscrew.

e. Screw plate with thumbscrew, plan view showing design on screw plate. 

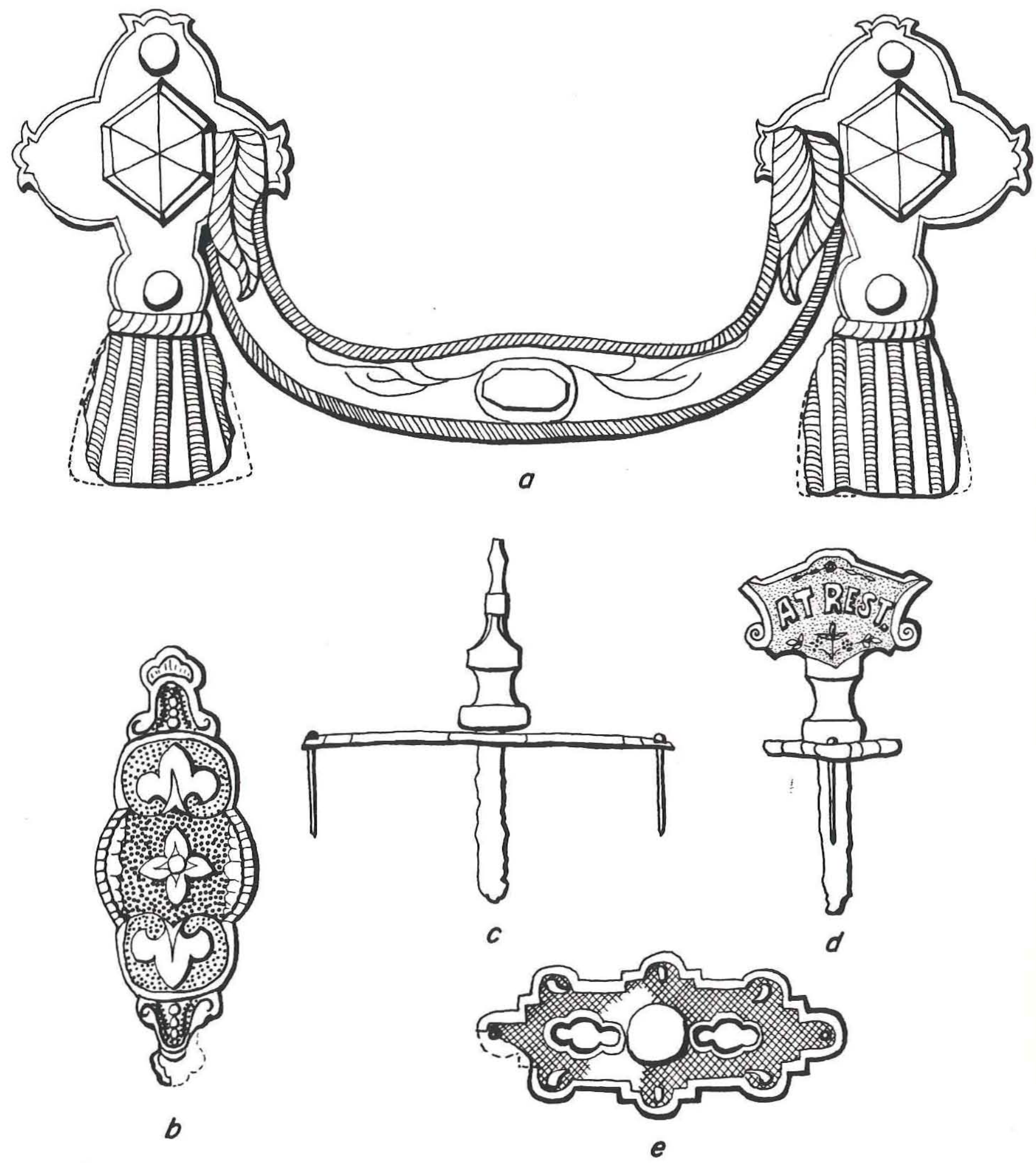


\section{DISCUSSION}

The Laredo Cemetery Site is an unusual and important site for archeologists in that basic archeological excavations as opposed to standard exhumation and relocation of an historic (nonaboriginal) cemetery previously have not been undertaken in Texas; it is certain, however, that similar sites will be encountered in the future. Any conclusions drawn from the present investigations must be regarded as tenuous due to a multiplicity of extenuating circumstances. First and foremost among these problems are the circumstances leading to the discovery and subsequent partial excavation of the site which resulted in the employment of less than preferred methods of investigation as described in the Archeological Procedures section. The limited nature of the sampling relative to the total size of the cemetery, the lack of conclusive evidence concerning the cemetery size, ownership, number of persons interred, ethnicity and religious affiliations, as discussed in the Introduction, posed additional problems.

Thirty-six graves were identified at 4lWB22. Eight graves were completely removed, fourteen were partially removed, one was completely removed by the backhoe and totally destroyed, and thirteen were detected but were not exhumed or disturbed (Table 1). It was possible to ascertain only minimal demographic information due to the recovery methods employed. It was determined that nine adult males, eight adult females and four adults and two subadults of undetermined sex were present (Table 2). The present analysis is of a too limited scope to attempt to determine ethnicity. Judging from the time period during which the cemetery was actively used, it is logical that both Anglos and Hispanics were interred in it. 
This cemetery did contain a Catholic section as reported in the Historical Background section; however, it is beyond the scope of this report to fully investigate the religious implications. The remains associated with Grave 8-1 represent the only obvious religious affiliations with the Catholic Church and also represent the only instance in which the cause of death is apparent; the woman and infant presumably died during childbirth. No other grave exhibited religious affiliations in the form of personal effects or coffin decoration.

A total of five coffins were decorated with hardware in the form of handles, studs, screw plates with thumbscrews, and other decorative items. Analysis of these materials indicates that this hardware was inexpensive and was designed specifically for aesthetic decorative purposes, $i_{. e}$, the base metal used in the handles consists of zinc alloys. Of the five coffins with hardware, three contained the remains of males (Graves $1-7,5-1$ and $8-3$ ), one the remains of an adult female and infant (Grave 8-1), and one the remains of a subadult of undetermined sex (Grave 4-1). Tables 3 and 4 summarize the distribution of cultural materials in the excavated graves.

It is significant to note that the subadult in Grave 4-1 and the young adult female and infant in Grave 8-1 were attributed special consideration. The overall styles of these two coffins, including shape and decoration (paint and hardware), differs markedly from the coffins used in the other interments. It is equally important to note that, given the special treatment of these two interments, only Grave 8-1 was accorded religious importance. However, in a general sense, the hardware 
TABLE 1

DISTRIBUTION OF IDENTIFIED GRAVES

\begin{tabular}{|c|c|c|c|c|c|}
\hline Provenience & $\begin{array}{l}\text { Total \# } \\
\text { Graves }\end{array}$ & $\begin{array}{l}\text { Completely } \\
\text { Removed }\end{array}$ & $\begin{array}{l}\text { Partially } \\
\text { Removed }\end{array}$ & $\begin{array}{l}\text { Recorded, } \\
\text { Not Examined }\end{array}$ & $\begin{array}{l}\text { Not Exhumed, } \\
\text { Resealed }\end{array}$ \\
\hline Pit 1 & 8 & 2 & 4 & 1 & 1 \\
\hline Pit 2 & 1 & - & - & - & 1 \\
\hline Pit 3 & 3 & 1 & 2 & - & - \\
\hline Pit 4 & 3 & 1 & 2 & - & - \\
\hline Pit 5 & 2 & 1 & 1 & - & - \\
\hline Pit 6 & 2 & 1 & 1 & - & - \\
\hline Pit 7 & 2 & 2 & - & - & - \\
\hline Pit 8 & 4 & - & $3 *$ & - & 1 \\
\hline Pit 9 & 0 & - & - & - & - \\
\hline Pit 10 & 1 & - & 1 & - & - \\
\hline Foundation & 8 & - & - & - & 8 \\
\hline Sewer Trench & 0 & - & - & - & - \\
\hline \multicolumn{5}{|l|}{ Water Line } & 2 \\
\hline TOTALS: & 36 & 8 & 14 & 1 & 13 \\
\hline $\begin{array}{ll}\text { *Note: } & \text { Grave } \\
& \text { only } \\
& \text { remov }\end{array}$ & $\begin{array}{l}\text { 8-1 cont } \\
\text { partially } \\
\text { ed. }\end{array}$ & $\begin{array}{l}\text { ained two in } \\
\text { removed and }\end{array}$ & $\begin{array}{l}\text { dividuals; } \\
\text { the infant }\end{array}$ & $\begin{array}{l}\text { the adult fema } \\
\text { was completel }\end{array}$ & le was \\
\hline
\end{tabular}

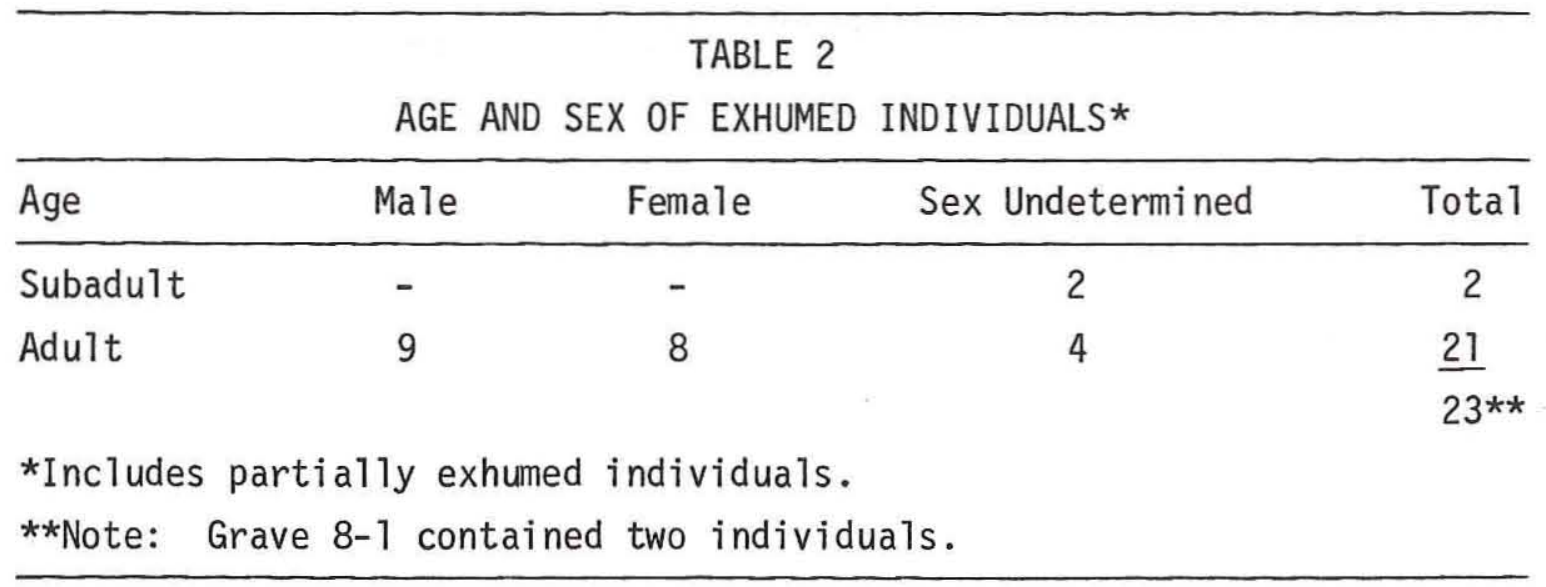




\begin{tabular}{|c|c|c|c|c|c|}
\hline & & $\begin{array}{l}\text { TA } \\
\text { STRIBUTION OF }\end{array}$ & $\begin{array}{l}3 \\
\text { TURAL MATE }\end{array}$ & & \\
\hline Grave & $\begin{array}{l}\text { Personal } \\
\text { Effects }\end{array}$ & $\begin{array}{l}\text { Utilitarian/ } \\
\text { Implement }\end{array}$ & $\begin{array}{l}\text { Coffin } \\
\text { Hardware }\end{array}$ & Age & Sex \\
\hline $1-1$ & $x$ & - & - & adult & $?$ \\
\hline $1-2$ & - & - & - & adult & M? \\
\hline $1-3$ & $x$ & - & - & adult & $\mathrm{F}$ \\
\hline $1-4$ & - & - & - & adult & M? \\
\hline $1-5$ & - & - & - & adult? & $?$ \\
\hline $1-7$ & $x$ & - & $x$ & adult & M? \\
\hline $3-1$ & $x$ & - & - & adult & $\mathrm{F}$ \\
\hline $3-2$ & - & - & - & adult & $M ?$ \\
\hline $3-3$ & - & - & - & adult & $\mathrm{F}$ \\
\hline 4- 1 & $x$ & - & $x$ & subadult & $?$ \\
\hline $4-2$ & $x$ & - & - & adult & $\mathrm{F}$ \\
\hline $4-3$ & $x$ & - & - & adult & $M$ \\
\hline $5-1$ & $x$ & $x$ & $x$ & adult & $M$ \\
\hline $5-2$ & - & - & - & adult & $?$ \\
\hline $6-1$ & - & - & - & adult & $\mathrm{F}$ \\
\hline $6-2$ & - & - & - & adult & $?$ \\
\hline $7-1$ & $x$ & $x$ & - & adult & $\mathrm{F}$ \\
\hline $7-2$ & $x$ & - & - & adult & $\mathrm{F}$ \\
\hline $8-1$ & $x$ & - & $x$ & $\begin{array}{l}\text { adult } \\
\text { infant }\end{array}$ & $\begin{array}{r}\mathrm{F} \\
?\end{array}$ \\
\hline $8-2$ & - & - & - & adult & M? \\
\hline $8-3$ & - & - & $x$ & adult & M \\
\hline $10-1$ & $x$ & - & - & adult & M \\
\hline
\end{tabular}




\begin{tabular}{|c|c|c|c|c|c|c|c|c|c|c|c|c|}
\hline \multicolumn{12}{|c|}{$\begin{array}{c}\text { TABLE } 4 \\
\text { ARTIFACT SUMMARY }\end{array}$} & \multirow[t]{2}{*}{ s. } \\
\hline & \multicolumn{4}{|c|}{ Coffin Hardware } & \multicolumn{2}{|c|}{ Buttons } & \multicolumn{5}{|c|}{ Miscellaneous } & \\
\hline $\begin{array}{l}\text { Grave } \\
\text { No. }\end{array}$ & Handles & Studs & Screwplates & Other & Ceramic & Metal & Other & Jewelry & $\begin{array}{l}\text { Shoe } \\
\text { Fragments }\end{array}$ & Utility & Coins & Other \\
\hline $1-1$ & - & - & - & - & 1 & - & - & - & - & - & - & - \\
\hline $1-3$ & - & - & - & - & - & - & - & - & 2 & - & - & - \\
\hline $1-4$ & - & - & - & - & - & 3 & - & - & - & - & - & - \\
\hline $1-7$ & 2 & 2 & 2 & - & - & 2 & - & - & - & - & - & - \\
\hline $3-1$ & - & - & - & - & 6 & 4 & - & - & - & - & - & - \\
\hline $4-1$ & 4 & 4 & 3 & - & 4 & - & - & 1 ring & - & - & - & - \\
\hline $4-2$ & - & - & - & - & 1 & 3 & $\begin{array}{l}1 \text { (wooden) } \\
1 \text { (she } 11 \text { ) }\end{array}$ & 1 ring & - & - & - & - \\
\hline $4-3$ & - & - & - & - & 3 & 4 & - & - & - & - & - & - \\
\hline $5-1$ & - & - & 2 & - & 2 & 1 & - & - & - & $\begin{array}{l}1 \text { pair } \\
\text { scissors }\end{array}$ & $\begin{array}{l}11890 \\
\text { nickel }\end{array}$ & - \\
\hline $7-1$ & - & - & - & - & 3 & 2 & - & - & 2 & $\begin{array}{l}1 \text { Sad } \\
\text { iron }\end{array}$ & - & - \\
\hline $7-2$ & - & - & - & - & 1 & - & - & - & - & - & - & - \\
\hline $8-1$ & 4 & 8 & 5 & $\begin{array}{l}1 \text { large } \\
\text { cross }\end{array}$ & - & - & 1 (she11) & - & - & - & - & $\begin{array}{l}38 \text { rosary } \\
\text { beads and } 1 \\
\text { metal cross }\end{array}$ \\
\hline $8-3$ & 4 & 1 & 2 & - & - & 1 & - & - & - & - & - & - \\
\hline $10-1$ & - & - & - & - & 1 & 2 & 1 (wooden) & - & - & - & - & - \\
\hline TOTALS & $: 14$ & 15 & 14 & 1 & 22 & 22 & 4 & 2 & 4 & 2 & 1 & 39 \\
\hline
\end{tabular}


present in Graves 1-7, 4-1, 5-1, 8-1 and 8-3 is strikingly similar in style and construction.

The truncated diamond style of the coffins is generally uniform throughout the cemetery, with the two exceptions (Graves $4-1$ and 8-1) noted previously. A discussion of the materials used in coffin construction is contained in Appendix III.

There is a certain consistency in the orientation of the long axis of the coffins. Twenty-two of the excavated coffins are oriented east-west; however, the direction of the head placement varies. Seven individuals are interred with their heads to the east and fifteen with their heads to the west. Although not exhumed or fully investigated, it appears that Graves 1-6 and 8-4 are oriented east-west.

Only one interment, Grave 6-2, is oriented on a north-south axis; the head is placed to the south. Whether this unique case of orientation is related to the period of burial, or if it is just a question of space, poses an interesting question.

Disposal of the dead has been a preoccupation of man since early prehistoric times. The decision to bury a body rests on social and economic considerations and pressures. Economic variables provide partial explanations for the form and style of burial which is represented at the Laredo Cemetery Site. The variables suggested by the styles of these interments also provides some information about the lives of the people.

The widespread custom of burying articles of various kinds with the deceased has facilitated our gradual enlightenment of those who inhabited the world before us, both in prehistoric as well as historic times. 
Because there are no known extant written records for the Laredo Cemetery Site, the physical remains and the items interred with them are, as in prehistoric cemeteries, our only clues to the identity, habits, surroundings and mode of life of these individuals.

The articles recovered from 41WB22 may be grouped into two categories, personal effects and utilitarian items, which portray different facets of the lives of these people. It is possible that the scissors recovered from Grave 5-1 and the iron in Grave 7-1 represent items considered to be of utilitarian importance, $i . e$. , an indication of the occupation of these individuals. However, it is also possible that these items were of sentimental importance only. Undoubtedly the 1890 coin associated with Grave 5-1 and the rings made of nonprecious metals associated with Graves 4-1 and 4-2 indicate personal attachment. The presence of the rosary from Grave 8-1 probably indicates this same type of personal significance in addition to the obvious religious importance.

It is not within the scope of this report to attempt to thoroughly unravel the ideological, sociological and religious implications of the deathway represented here. Comparative examples are necessary for an analysis in which attention is focused on the fate of the deceased. However, psychological explanations of particular forms of burial, unlike economic explanations, deal directly with the context of the rituals of death themselves. The prevalence of emotions such as fear and guilt, as evidenced in mode of burial (Huntington and Metcalf 1979: 194) is especially indicated in Grave 4-1 and Grave 8-1.

The focus of this report has been upon the documentation of the physical and material remains recovered from 
41WB22, the Laredo Cemetery Site. However, it is significant to examine the circumstances which resulted in the need for partial excavation of this site. It does not seem possible to "lose" this cemetery when it is considered that it was probably in use as late as the $1920^{\prime} \mathrm{s}$, that it was clearly within the limits of an incorporated town while in use, and that in size it covers two entire city blocks. These circumstances are compounded further by the fact that when the Boy's Club was built in 1940, it is reported that coffins were indiscriminantly removed from the western portion of the site, yet no steps were taken to relocate the graves. The intent of reviewing these events is not to lay blame for neglect and/or oversight that resulted in these circumstances in Laredo, for it is known that cemeteries ranging in size from small family plots to large government-owned plots (e.g., st. Louis Cemetery in Paris, France, see Appendix IV) are constantly being forgotten, built over and then rediscovered. The point is that similar circumstances will undoubtedly occur again and archeologists must address themselves to this type of problem.

That other information must be integrated with the archeological data in a case such as this is unquéstionable. Future investigations should include detailed examination and analysis of the religious, socio-economic, psychological and ideological considerations pertaining to the human remains. The results would serve as the basis for verifying statements regarding deathways in particular cultures and/or areas in which both written and physical archeological evidence are utilized. 


\section{GLOSSARY}

casket - a rectangular burial receptacle with perpendicular sides (first made in the second half of the nineteenth century).

coffin - a hexagonally shaped burial receptacle which tapers out from the head or top to the area of the shoulders, where it is widest, and then tapers in to the feet.

ear piece - the portion of the coffin handle located on each end of the actual handle section, which attaches to the coffin or casket.

screw plate/thumbscrew - ornamental hardware used on both coffins and caskets and which consists of compound horizontal and vertical pieces.

stud - ornamental hardware used on coffins and caskets. truncated - or truncated diamond style coffin refers to the shape which is widest at the shoulder and tapers inward toward the foot and the head.

*The terms used to describe the coffin hardware are from C. Rogers \& Bros. IZZustrated and Descriptive Catalogue of Coffin and Casket Trimmings (1882). 


\section{REFERENCES CITED}

Arbingast, Stanley A., Lorrin G. Kennamer, Robert H. Ryan, James R. Buchanan, William L. Hezlep, L. Tuffley Ellis, Terry G. Jordan, Charles T. Granger, and Charles P. Zlatkovich

1976 Atzas of Texas. Bureau of Business Research, The University of Texas at Austin.

Blair, W. Frank

1950 The Biotic Provinces of Texas. The Texas Journal of Science 2(1): 93-116.

Bolton, Herbert Eugene

1970 Texas in the Middle 18th Century. The University of Texas Press, Austin and London.

Carr, John T., Jr.

1967 The Climate and Physiography of Texas. Texas Water Development Board Report 53 , Austin.

Carter, E. Suzanne and Crystal S. Ragsdale

1976 Biegel Settlement: Historic Sites Research, Fayette Power Project. Texas Archeological Survey, The University of Texas at Austin, Research Report No. 59.

Dunne, Monsignor Kevin

1980 Letter from Msgr. Dunne of Christ the King Church, P. O. Box 1848, Laredo, Texas 78040 .

Falvella, J. William (city editor)

1925 An Historical Sketch of Laredo. Laredo Times Special Edition.

Fenneman, Nevin M.

1938 Physiography of Eastern United States: 100-120. McGraw-Hill, New York and London.

Foster, E. J.

1918 1890's Perspective Map of the City of Laredo. In: 1920-21 City Directory, Vol. II, Reedmont Publishing Co.

Fox, Daniel E.

1979 Archaeological Testing at Ft. McIntosh, Laredo Junior College Campus, Laredo, Texas. Center for Archaeological Research, The University of Texas at San Antonio, Archaeological Report No. 68. 
Fox, Daniel E. and H. G. Uecker

1977 An Archaeological Study of the McPherson Road

Extension Project. Center for Archaeological

Research, The University of Texas at San Antonio, Archaeological Survey Report No. 45.

Garcia, Rogelia O.

1970 Dolores, Revilza and Laredo (Three Sister Settlements). Texian Press, Waco.

Gilmore, Kathleen Kirk

1969 The San Xavier Mission: A Study in Historical Identification. State Building Commission, Archeological Program Report No. 16, Austin.

Godfrey, Curtis L., Gordon S. McKee and Harvey Oakes

1973 General Soils Map of Texas. Texas Agricultural Experiment Station, Texas A\&M University, in cooperation with the Soil Conservation Service, United States Department of Agriculture.

Hall, Grant D.

1973 Report of Archeological Investigations: Zacate Creek Flood Control Project, Laredo, Texas. Texas Archeological Survey, The University of Texas at Austin, Technical Bulzetin No. 3.

Haynes, J. L. (translator)

1767 Acta de la General Visita del Pueblo de San Agustin de Laredo. Translation on file, General Land Office; filed in 1871.

Huntington, Richard and Peter Metcalf

1979 Celebrations of Death: The Anthropology of Mortuary Ritual. Cambridge University Press, Cambridge.

Israel, Fred L. (editor)

19761897 Sears, Roebuck Catalogue. Chelsea House Publishers, New York.

Ivey, J. E., T. Medlin and J. D. Eaton

1977 An Initial Archaeological Assessment of Areas Proposed for Modification at Ft. McIntosh, Webb County. Center for Archaeological Research, The University of Texas at San Antonio, Archaeological Survey Report No. 32.

Newcomb, W. W. , Jr.

1958 The Skeleton of Yellowhouse Canyon. Texas Memorial Museum, Museum Notes No. 8, Austin. 
Paiz, Alfredo, Jr.

1980 Personal communication on April 29, 1980, from Alfredo Paiz, Superintendent in charge of construction for Century Structures, Inc., Laredo, Texas.

Rogers, C. and Bros.

1882 Descriptive Catalog of Coffin and Casket Trimmings. Springfield Printing Co., Springfield, Mass.

Schuetz, Mardith K.

1968 Archeology of Mission San Juan Capistrano, San Antonio, Texas, Volume I (of two volumes). State Building Commission, Archaeological Program Report No. 10 .

Sellards, E. H., W. S. Adkins and B. F. Plummer

1932 The Geology of Texas, Vol. 1: Stratigraphy. University of Texas Bulletin No. 3232.

Suhm, Dee Ann

1962 The White Site: An Historical Indian Burial in Yoakum County, Texas. Bulletin of the Texas Archeological Society 32: 85-119.

Yeoman, R. S.

1976 A Guide Book of United States Coins. 29th Revised Edition. Western Publishing Co., Raine, Wisconsin. 


\title{
ADDITIONAI REFERENCES REGARDING \\ FUNERARY PRACTICES
}

\author{
Bowman, LeRoy \\ 1959 A Study in Guilt, Extravagance and Sublimity. \\ Public Affairs Press, Washington, D.C. \\ Concord Antiquarian Society \\ 1969 Two Hundred Years of Funerary Arts and Customs of \\ Concord, Massachusetts. Concord Press Corp., \\ Concord. \\ Gorer, Geoffrey \\ 1965 Death, Grief and Mourning. Doubleday \& Co., Inc., \\ Garden City, New Jersey. \\ Grollman, Earl A. (editor) \\ 1974 Concerning Death: A Practical Guide for the Living. \\ Beacon Press, Boston. \\ Habenstein, Robert Wesley \\ 1955 American Funeral Directing. Bulfin Printers, \\ Milwaukee. \\ Habenstein, Robert Wesley and William M. Lamers \\ 1960 Funeral Customs the World Over. Bulfin Printers, \\ Milwaukee. \\ Harrah, Barbara K. and David F. Harrah \\ 1976 Funeral Service: A Bibliography of Literature on \\ its Past, Present and Future, The Various Means of \\ Disposition and Memoralization. The Scarecrow \\ Press, Inc., Metuchen, New Jersey. \\ Hasluck, Paul D. (editor) \\ n.d. Coffin Making and Undertaking. [ca. 1928] Funk \\ and Wagnalls, New York. \\ Jackson, Charles o. \\ 1977 Passing: The Vision of Death in America. Greenwood \\ Press, Westport, Connecticut. \\ Jones, Barbara \\ 1967 Design for Death. The Bobbs-Merrill Company, Inc., \\ Indianapolis. \\ Mitford, Jessica \\ 1963 The American Way of Death. Simon and Shuster, New \\ York.
}


Morgan, Ernest

1964 A Manual of Simple Burial. The Celo Press, Burnsville, North Carolina.

Mossman, B. C. and M. W. Stark

1971 The Last Salute: Civil and Military Funerals 1921-1969. Department of the Army, Washington, D.C.

Ogden, C. K. (editor)

1930 Death Customs. Kegan Paul, French, Trubner \& Co., Ltd., New York.

Pine, Vanderlyn and R. Pine

1975 Caretaker of the Dead: The American Funeral

Director. Irvington Publishers, Inc., New York.

Puckle, Bertram S.

1926 Funeral Customs: Their Origins and Developments. T. Werner Laurie, Ltd., London. 
APPENDIX I: ADDITIONAL MONITORING

Mary Jane McReynolds 
ADDITIONAL MONITORING

Archeological investigations of the eastern portion of 41WB22 were completed on June 5, 1980, when all modifications necessary for the construction of the Laredo Transit operating Facilities involving cultural resources were executed. These final excavations included enlargement of Pit 2; excavation of Pit 9, a 4x4-feet mud and oil pit; excavation of Pit 10 , a 4x4-feet wash area pit; excavation of a sewer line trench; and excavation of a water line trench.

Pit 2 , an $8 \times 20$-feet service pit, was enlarged 15 feet to the north and to a depth of 6 feet 4 inches (Fig. 4). A cavity was visible in the northeast corner of the pit when work by the backhoe was completed. Closer examination revealed that a grave was located to the north of the pit wall; however, the coffin was not visible. Clean sand was packed into the collapsed area to reseal this grave.

Pit 9, a mud and oil inceptor pit located immediately south of the foundation area (Fig. 4), was excavated to a depth of approximately 6 feet without encountering any interments.

Pit 10, a bus wash area pit located east of Pit 1 (Fig. 19), was excavated to a depth of approximately 5.5 feet; one grave was encountered. Grave 10-1 was partially exposed as it extended from the north and west walls of the pit. Oriented east-west, with the head placed to the west, the coffin lay 5.7 feet below the ground surface. Because only a portion of the total coffin was exposed and because of its extremely disarticulated condition, it was not possible to determine the dimensions of the coffin. It was also not possible to determine whether the coffin was truncated; however, since all interments recorded at this site are truncated coffins, it is reasonable to assume that this coffin is of the same style. 
The skeleton lies fully extended, face up, with the arms crossed over the abdomen. The west wall of the pit intersects the body immediately above the pelvis. Due to the collapsed state of the coffin, the exposed remains are completely disarticulated.

Cultural materials associated with this interment included one white porcelain button, two metal buttons, and one wooden button, all of which were recovered from the pelvic area.

The sewer line trench, 175 feet long and 20 inches wide, was excavated to an inclined depth of 3.5 feet to 5 feet. No graves were detected.

Excavation of the water line trench, 180 feet long and 2 feet wide by 2 feet deep, resulted in the location of two graves as indicated by collapsed or caved-in areas. The coffins and their contents were not exhumed; clean sand are packed into the cavities to reseal these graves. 


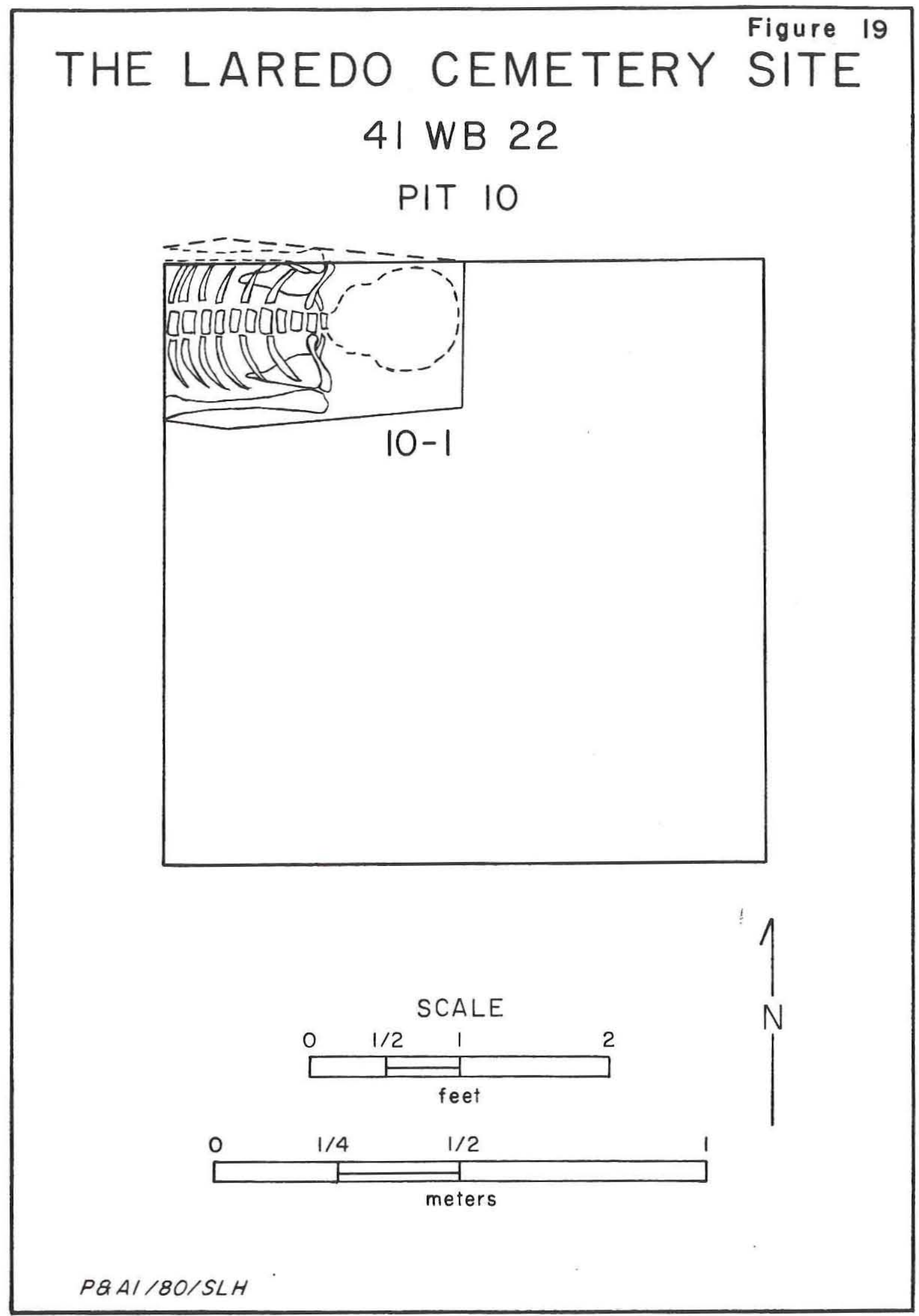




\section{APPENDIX II: A PRELIMINARY ANALYSIS OF SKELETAL REMAINS FROM THE LAREDO CEMETERY SITE}

LaVerne Herrington Mary Jane McReynolds 


\section{A PRELIMINARY ANALYSIS OF SKELETAL REMAINS FROM THE LAREDO CEMETERY SITE}

The skeletal sample recovered from 41 WB2 2 ranges in age from infant to elderly. An annotated outline of attributes of disposal of the deceased can be found in Table 5 . The form of disposal is a simple singular operation involving one individual with the exception of Grave 8-1 which contained two individuals. The positioning of the body was uniformly dorsal (i.e., lying on the back). The relationship of segments of the body included full extension with arms crossed over the abdominal area or along the side of the body. It is unfortunate that this preliminary analysis cannot be expanded to study more detailed aspects of these skeletal materials due to the unusual excavation procedure and subsequent reinterment of the remains.

Graves 1-1 through 1-5 were removed prior to archeological investigation; minimal information is ascertained from the amount of skeletal material recovered.

Grave 1-1: This individual is an adult.

Grave 1-2: The grave contains the remains of an adult male(?).

Grave 1-3: The remains of an adult female were recovered.

Grave 1-4: This individual is judged to be an adult male (?) .

Grave 1-5: This grave contains the remains of an adult, sex undetermined.

Grave 1-7: This grave contains the remains of an adult male, judged from robusticity and size of bones; the state of preservation is good.

Grave 3-1: This badly disarticulated individual is judged to be an adult (35-40?) male; however, the post 
cranial materials are incomplete. Reburial is indicated. Grave 3-2: This grave contains the remains of an adult male in a good state of preservation; no abnormalities or deformities were noted.

Grave 3-3: This grave contains the remains of an adult female, judged from the sacrum; the state of preservation is excellent.

Grave 4-1: This grave contains the remains of one subadult; sex is undeterminable.

Grave 4-2: This is apparently the remains of an adult, although the skeletal material is in very poor condition.

Grave 4-3: The skeletal material is fragmentary and in a poor state of preservation. This individual is judged to be an adult male although this identification is uncertain.

Grave 5-1: This individual is judged to be an old and ill adult male with marked pathology.

Grave 5-2: These remains are judged to be an adult with age and sex undeterminable.

Grave 6-1: The skeletal material recovered from this grave is in a very poor state of preservation; this individual is judged to be an adult female.

Grave 6-2: It is not possible to determine the sex or age of this adult individual inasmuch as only the patella, tibia, fibula, calcanius and phalanges are present.

Grave 7-1: The remains from this grave are in a very poor state of preservation; they are fragmentary and decomposed. This individual is judged to be an adult female of 20 to 25 years of age. 
Grave 7-2: The remains from this interment are determined to be that of an adult female; discrepancies in the data preclude any further statement.

Grave 8-1: This grave contains the skeletal material of two individuals, an adult female age 20-30 (?) and a premature or newborn infant. No deformities or abnormalities were noted.

Grave 8-2: The remains from this interment are an adult male in an excellent state of preservation.

Grave 8-3: The remains of this individual are judged to be that of an adult male; the skeletal material is in a poor and fragmented state.

Grave 10-1: This grave contains the remains of an adult male in an excellent state of preservation. 
TABLE 5:

SUMMARY OF EXCAVATED GRAVES

\begin{tabular}{|c|c|c|c|c|c|}
\hline $\begin{array}{l}\text { Orien- } \\
\text { tation }\end{array}$ & $\begin{array}{l}\text { Grave } \\
\text { Number }\end{array}$ & $\begin{array}{l}\text { Exposed/ } \\
\text { Removed }\end{array}$ & $\underline{\text { Age }}$ & $\underline{\text { Sex }}$. & $\begin{array}{l}\text { Abnormalities or } \\
\text { Deformities/Condition }\end{array}$ \\
\hline$E$ & $1-1$ & Completely & Adult & ? & *Note: Graves 1-1 through 1-6 \\
\hline E & $1-2$ & Partially & Adult & M? & were destroyed prior to \\
\hline ) & $1-3$ & Partially & Adult & $\mathrm{F}$ & \\
\hline $\mathrm{E}$ & $1-4$ & Completely & Adult & M? & \\
\hline $\mathrm{E}$ & $1-5$ & Partially & Adult & $?$ & \\
\hline & $1-7$ & Partially & Adult & M? & None \\
\hline & $1-8$ & Completely & - & - & - \\
\hline & $3-1$ & Completely & Adult & M & $\begin{array}{l}\text { Extreme disarticulation; } \\
\text { reburial is indicated; } \\
\text { post cranial material } \\
\text { incomplete }\end{array}$ \\
\hline E & $3-2$ & Partially & Adult & M? & None \\
\hline E & $3-3$ & Partially & Adult & $\mathrm{F}$ & None \\
\hline$F$ & 4- 1 & Completely & Subadult & $?$ & None \\
\hline - & $4-2$ & Partially & Adult & $\mathrm{F}$ & None \\
\hline ᄃ & $4-3$ & Partially & Adult & M & None \\
\hline$F$ & $5-1$ & Completely & Adult & M & $\begin{array}{l}\text { Marked pathology; old and } \\
i 11 \text {; knobs of calcium on } \\
\text { long bones; ilium almost } \\
\text { transparent }\end{array}$ \\
\hline & $5-2$ & Partially & Adult & $?$ & None \\
\hline & $6-1$ & Completely & Adult & $\mathrm{F}$ & $\begin{array}{l}\text { None; poorly preserved; } \\
\text { fragmentary }\end{array}$ \\
\hline & $6-2$ & Partially & Adult & $?$ & Remains are fragmentary \\
\hline & $7-1$ & Completely & Adult & $\mathrm{F}$ & $\begin{array}{l}\text { None; remains fragmentary; } \\
\text { decomposed }\end{array}$ \\
\hline & $7-2$ & Completely & Adult & $\mathrm{F}$ & Discrepancy in data \\
\hline & $8-1$ & Partially & $\begin{array}{l}\text { Adult \& } \\
\text { Infant }\end{array}$ & $\mathrm{F}$ & $\begin{array}{l}2 \text { individuals; none on } \\
\text { adult; infant premature, } \\
\text { newborn or stillborn }\end{array}$ \\
\hline & $8-2$ & Partially & Adult & M? & None; excellent condition \\
\hline$E-$ (W) & $8-3$ & Partially & Adult & M & None; fragmented condition \\
\hline E) $-W$ & $10-1$ & Partially & Adult & M & None; good preservation \\
\hline
\end{tabular}


APPENDIX III: IDENTIFICATION OF WOOD USED IN COFFIN CONSTRUCTION, THE LAREDO CEMETERY SITE

Ken E. Rogers

Mary Jane McReynolds 
During the excavation of 41 WB22, wood samples from nineteen coffins were collected from the thirty-six interments encountered. Of that number, twelve samples were processed for identification purposes. At least one sample from each pit containing graves was selected for analysis with the exception of Pits 5 and 10. It was not possible to collect a sample from the coffins in these pits due to the small amount of the coffins which were exposed within the confines of these two pits and to the deteriorated condition of the wood. Also, the sample submitted from Grave 1-7 was too decomposed to be identified.

Identification was made on the basis of the gross structural features visible with a $10 \mathrm{x}$ hand lens. The samples were decomposed to the extent that it was not possible to utilize standard features such as color, smell and minute wood structure in the analysis. This somewhat compromises the exactness of the identification; however, for the purposes of this report, the extent of the identification is considered to be adequate.

Three genera, Cedar, Spruce and Southern Yellow Pine, were identified from the samples which were submitted (Table 6). It was not possible, however, for the identification to be carried to the species level. Therefore, the genus cedar could be any species such as Western Red Cedar, Eastern Red Cedar or any other less prevalent cedars in the United States. The spruce could be any of the species such as Sitka, Black, White, etc. The samples identified as Southern Yellow Pine could be any of the Southern Yellow Pines such as Ponderosa, Shortleaf, etc.

All of these conifers exhibit a wide distribution of their general habitat as described in Brockman (1968) and Petrides (1972). The species of cedar which could be Western Red Cedar (Thuja plicata), Eastern Red Cedar 
(Juniperus virginiana) and others represent an extremely wide distribution area ranging from southern Canada to northeastern Texas. It is possible that the samples of Southern Yellow Pine could be any of several North American evergreen trees having yellowish wood, such as Shortleaf (Pinus echinata) or Ponderosa (Pinus ponderosa). Distribution of these species also exhibit a wide general habitat from the northeastern states (New York, Pennsylvania, Missouri, Illinois) to northeast Texas. The species of spruce which could be Black (Picea mariana), White (Picea grauca), Sitka (Picea sitchensis) or others are found primarily in Canada and the northern United States.

The predominant type of vegetation found in the study area is thorny brush, including mesquite (Prosopis julifloral and various species of Acacia and Mimosa, granjeno (Celtis pallida), cenizo (Leucophyllum texanum), prickly pear (Opuntia lindheimeri) and tasajillo (Opuntia leptocaulis) to name a few (Blair 1950: 103). It is apparent then that the native species were not being utilized in coffin construction in Laredo.

It is probable that the finished products were imported. This is supported in particular by the coffins observed in Graves 4-1 and 8-1 (Fig. 4). Both coffins were decorated, $i . e .$, both were painted, ornamented with hardware, and exhibited a slightly different shape from any of the other coffins observed at this site. The coffin in Grave 8-1 was the most unique because of the obvious religious significance evidenced in the coffin hardware and because of the "window" in the lid of the coffin. It is highly unlikely that it was constructed locally. However, it is probable that raw 
TABLE 6

WOOD TYPES FROM COFFINS RECOVERED FROM

THE LAREDO CEMETERY SITE

\begin{tabular}{|c|c|}
\hline Grave No. & Type of Wood \\
\hline $1-3$ & Southern Yellow Pine \\
\hline $1-7$ & $\begin{array}{l}\text { Too decomposed for } \\
\text { identification }\end{array}$ \\
\hline $3-1$ & Southern Yellow Pine \\
\hline $3-3$ & Spruce \\
\hline $4-1$ & Cedar \\
\hline $4-3$ & Southern Yellow Pine \\
\hline $6-1$ & Southern Yellow Pine \\
\hline $6-2$ & Spruce \\
\hline $7-1$ & Southern Yellow Pine \\
\hline $7-2$ & Southern Yellow Pine \\
\hline $8-1$ & Cedar \\
\hline $8-3$ & Spruce \\
\hline
\end{tabular}

Decorated/Undecorated Coffin

Undecorated

Decorated

Undecorated

?

Decorated (painted)

Undecorated

Undecorated

Undecorated

Undecorated

Undecorated

Decorated (painted)

Decorated 
materials were imported and that coffins were constructed locally. This is supported by the varying sizes of coffins which indicate that the majority encountered at the Laredo Cemeter site were constructed in direct proportion to an individual's measurements (e.g., Fig. 5 , Pit 1, All Graves). 


\section{REFERENCES CITED}

Blair, W. Frank

1950 The Biotic Provinces of Texas. The Texas Journal of Science 2(1): 93-116.

Brockman, C. Frank

1968 Trees of North America. Golden Press, New York.

Petrides, George A.

1972 A Field Guide to Trees and Shrubs, Second Edition. Houghton Mifflin Co., Boston. 
APPENDIX IV: A BRIEF HISTORY OF COFFINS

Mary Jane McReynolds 
A coffin is a burial receptable which tapers outward from the head or top to the area of the shoulders where it is widest, and then tapers inward toward the foot. Coffins and other receptacles used for transportation and disposal of the dead were not always used. Many early American colonists were simply wrapped in shrouds and interred, although wood was used to construct crude coffins relatively early in the Colonial Period. The term casket was not used until the second half of the nineteenth century when William Smith of Meriden, Connecticut, first manufactured rectangular burial boxes with perpendicular sides (Coffin 1976: 101).

It is unknown at this time whether this William Smith is the same person whose name appears on the coffin hardware recovered from Grave 4-1 and Grave 8-1 (see Figs. 10 and 16). A preliminary inquiry in which the U.S. Patent Office and the Connecticut State Library were consulted revealed no conclusive information.

A coffin was an inexpensive item in the seventeenth and eighteenth centuries and was usually fabricated by a local cabinetmaker upon demand. Country stores often stocked coffin hardware, screws with decorated heads, and sets of handles. Following the Civil War, however, the coffin became the largest single item of expense incurred for a funeral. The growth and proliferation of coffin shops in the nineteenth century is recognized as one of the most significant developments in the funeral business (Harmer 1963). Cabinetmakers realized that it was more profitable to manufacture a variety of items to display so they could create a demand. Competition became enthusiastic and by the end of the nineteenth century patents for a variety of coffins, caskets and other burial cases in almost every material imaginable were being issued. Although never 
successful commercially, items in stone, iron, potter's clay, zinc, glass, papier mache, aluminum, vulcanized rubber, and hydraulic cement were created in diverse shapes ranging from simple hexagons and rectangles to anthropoid forms with glass windows for viewing. Even a patent for an adjustable casket was issued (Harmer 1963: 90-91; Coffin 1976: 107).

Widespread concern about being buried alive resulted in the invention of extremely unusual systems such as a "life preserving coffin in case of doubtful death" with a spring lid that would fly open at the slightest movement. Similar coffins equipped with flags, bells and electrical alarms were produced for the purpose of detecting the presence of life following presumed death and preparation for interment. One patented model was set with an explosive charge to discourage tampering with a grave, whether the intent was to remove the deceased or to steal any valuables which were buried with the deceased (Harmer 1963: 106-107). The fear that the body would be debased underground was responsible for the invention of a metallic burial case designed to prevent decomposition. This type of coffin used in conjunction with embalming became popular because of its preservation capabilities.

A notable case if that of naval hero John Paul Jones who died in Paris, France, in the year 1792. He was buried in the St. Louis Cemetery in a governmentowned plot reserved for foreign Protestants and then was forgotten about until 1889 when the U.S. Ambassador to France began looking for his gravesite. The situation was similar to the Laredo Cemetery site in that the st. 
Louis Cemetery had been abandoned and subsequently covered by the expanding city. However, in 1895 the location of his gravesite was ascertained; permission to excavate was obtained from shopowners and residents and his body was found. Jones had been interred in a lead coffin which was filled with alcohol and straw. This resulted in the recovery of an extremely well-preserved body (Murfin 1980: 127).

As with any item of our material culture, coffins reflect changes in cultural concepts and technology and fashion. Items are manufactured during a dated time and mirror the rate of changing social, religious and economic values within a culture. So long as coffins were simply a burial receptacle and their period of show was brief, they occupied a minor place in American culture; however, when they became a matter of comparison and contrast, the desire for "status" resulted in an enthusiasm and inventiveness on the part of the makers and a willingness of the purchaser to succumb to the suggestion that "only the best will do." 
REFERENCES CITED

Coffin, Margaret M.

1976 Death in Early America. Thomas Nelson, Inc., Nashville.

Harmer, Ruth Mulvey

1963 The High Cost of Dying. The Crowell-Collier Press, New York.

Murfin, James V.

1980 Our Old Patriots Remains Don't Get to Rest in Peace. Smithsonian 11(2): 127-128. 